\title{
POINT PREVALENCE SURVEYS OF ANTIMICROBIAL USE: A SYSTEMATIC REVIEW AND THE
} IMPLICATIONS

Zikria Saleem ${ }^{1,2 *}$, Mohamed Azmi Hassali ${ }^{1}$, Brian Godman ${ }^{3,4,5}$, Ann Versporten ${ }^{6}$, Furqan Khurshid Hashmi ${ }^{7}$, Hamid Saeed $^{7}$, Fahad Saleem ${ }^{8}$, Muhammad Salman ${ }^{2}$, Inayat Ur Rehman ${ }^{9,10}$, Tahir Mehmood Khan ${ }^{11}$

${ }^{1}$ School of Pharmaceutical Sciences, Universiti Sains Malaysia, Malaysia

${ }^{2}$ Faculty of Pharmacy, The University of Lahore, Pakistan

${ }^{3}$ Health Economics Centre, University of Liverpool Management School, Liverpool, UK

${ }^{4}$ Department of Clinical Pharmacology, Karolinska Institute, Stockholm, Sweden

${ }^{5}$ Strathclyde Institute of Pharmacy and Biomedical Sciences, Strathclyde University, Glasgow, UK

${ }^{6}$ Laboratory of Medical Microbiology, Vaccine and Infectious Disease Institute, Faculty of Medicine and Health Sciences, University of Antwerp, Belgium

${ }^{7}$ University College of Pharmacy, University of the Punjab, Lahore, Pakistan

${ }^{8}$ Faculty of Pharmacy and Health sciences, University of Balochistan, Quetta, Pakistan

${ }^{9}$ Department of Pharmacy, Abdul Wali Khan University Mardan, Pakistan

${ }^{10}$ School of Pharmacy, Monash University Malaysia, Bandar Sunway

${ }^{11}$ Institute of Pharmaceutical Sciences, University of Veterinary and Animal Sciences, Pakistan

\section{Corresponding Author}

Zikria Saleem

Faculty of Pharmacy, The University of Lahore, Pakistan

Phone Number: +92322-9801981

Email ID: xikria@gmail.com

\section{(ACCEPTED FOR PUBLICATION: EXPERT REVIEW ANTI INFECTIVE THERAPY)}

\author{
Abstract: \\ Introduction: In view of increasing concerns with antimicrobial resistance (AMR), the World Health Organization \\ (WHO) instituted a Global Action Plan (GAP) to address this.
}

Area Covered: One of the strategies to achieve the goals of GAP is to conduct regular surveillance of antimicrobial use through point prevalence surveys (PPS). After systematic database screening of 2,893 articles, 60 PPS met the inclusion criteria and consequently were incorporated in this systematic review.

Expert Opinion: This review highlighted that most of the PPS were conducted in upper-middle and high-income countries. Prevalence of antimicrobial use was significantly higher in non-European hospitals compared with European hospitals. The domination of third-generation cephalosporin and fluoroquinolones use across all the regions suggests substantial use of broad-spectrum antimicrobials across countries. Among all identified regions around the world, India was the region where the highest use of antimicrobials was observed. Although PPS is a useful tool to assess the pattern of antimicrobial use and provides a robust baseline, however, a standardize surveillance method is needed. In order to optimize antimicrobial use, more efforts are required to improve the antimicrobial use.

Article Highlights: 
- Most of the point prevalence surveys were conducted in upper-middle and high-income countries.

- Prevalence of antimicrobial use was significantly higher in non-European hospitals compared with that European hospitals which can be a serious risk factor for resistance.

- India was the region where the highest use of antimicrobials was seen.

- The most frequently used antibiotics reported were the third-generation cephalosporins

- There were concerns with the lack and use of guidelines to direct antimicrobial use across countries.

Keywords: Point Prevalence Survey, Antimicrobial Prescribing, Review, Antimicrobial Resistance, Guidelines 


\section{INTRODUTION}

Antimicrobials have revolutionized the treatment of infectious diseases, becoming the cornerstone of treatment for infectious diseases to reduce morbidity and mortality [1-5]. However, there is increasing antimicrobial resistance (AMR) as a result of their overuse, which has become a serious problem worldwide [2,4,6,7]. Globally, increasing AMR rates has resulted in the use of more expensive broad-spectrum antibiotics that were earlier reserved for specific conditions $[2,3,7,8]$, along with increasing morbidity, mortality, and costs [9-13]. In view of increasing concerns with AMR and its impact, the World Health Organization (WHO) instituted a Global Action Plan (GAP) in the $68^{\text {th }}$ World Health Assembly in May 2015 [14-16]. In addition, during the United Nations (UN) General Assembly on $21^{\text {st }}$ September 2016, a declaration was made on AMR by the Heads of State, reinforcing the GAP. One of the goals of the GAP is to outline strategies to ensure the quality use of antibiotics thereby reducing inappropriate antibiotic use and associated AMR rates in the future [17,18]. One of the strategies to achieve these goals is to conduct regular surveillance of antimicrobial use through point prevalence surveys (PPS) [19]. As a result, a number of PPS have been conducted in different parts of world to improve future antibiotic use [19]. Point prevalence is the number of individuals with a condition divided by total number of all the individuals in that population in a time interval [20]. Point prevalence surveys (PPS) of antimicrobial use are typically conducted to determine the current in-patient use of antimicrobials to treat infections with the findings used to instigate pertinent quality improvement initiatives within hospitals [21-25].

It has been estimated that total antimicrobial usage, expressed in standard units, increased by $35 \%$ between 2000 to 2010, with Brazil, Russia, China, and South Africa alone accounting for $76 \%$ of this increase [26]. Moreover, there was an overall increase in the use of broad-spectrum antimicrobials including the carbapenems (45\%) [26]. Inappropriate use of antibiotics has always been a challenge, with inappropriate use increasing over time in some countries $[2,26]$. Irrational empirical antimicrobial prescribing for severe infections in hospitals is currently estimated at between $14.1 \%$ to $78.9 \%$ of in-patient use [27]. There are also a number of published systematic reviews showing patterns of inappropriate antibiotic use in non-hospitalized patients [28-30]. However, to the best of our knowledge, no systematic review has been conducted to evaluate antimicrobial use surrounding PPS in hospitalized patients, although we are aware of initiatives including the Global PPS which included data from 303 hospitals in 53 countries [25] as well as the recent Pan-European acute care hospital PPS involving 1209 hospitals among 28 countries in the European Union/ European Economic Area (EU/ EEA) [31]. Consequently, we sought to address this by analysing 
the burden of antimicrobial use measured through point prevalence surveys to provide direction to all key stakeholders in the future as we are aware that PPS can be used to establish quality initiatives for individual hospitals as well as monitor the effectiveness of any antimicrobial-stewardship (AMS) initiatives to improve future use [32]

\section{BODY:}

\subsection{Search strategy:}

All English language papers published in PubMed, EBSCO, Proquest, Cinahl and Scopus between January 2000 and December 2019 were searched. The Medical Subject Heading (MeSH) terms and keywords including "antimicrobial(s)", "antibiotic(s)", "use", "prescribing", "point prevalence", "repeated prevalence", "period prevalence", "survey" \& "hospital(s)" were used to identify the relevant literature as well as truncations and Boolean operators (“OR" \& “AND"). The titles of published papers and abstracts were subsequently screened in order to identify appropriate surveys reporting antimicrobial use.

\subsection{Inclusion and exclusion criteria}

Upon removal of duplicities, the full text of papers was retrieved and all original research articles (using an observational or experimental design) were considered for further assessment and inclusion in this systematic review. Potentially relevant articles were reviewed thoroughly in full-text. Original research papers that conducted a point prevalence survey of antimicrobial use in hospital settings were included in this systematic review. After a thorough discussion, the discrepancies in the selected articles were reviewed and possible studies were then reassessed to ascertain whether they met the broad content inclusion criteria of PPS or not. Antimicrobials were defined as antibacterials, antimycotics, and antivirals for systemic use. Antimicrobial use was categorized in children (including neonates and pediatrics) and adults (including surveys for the whole hospital). We included only surveys from acute care hospitals. Surveys conducted in intensive care units (ICU), home-based hospital care (HBHC), long-term care facilities (LTCFs) and nursing homes were excluded. Moreover, review articles, case studies, case series, and personal opinions were also excluded from this systematic review. In addition, studies involving antimicrobial consumption at outpatient clinics and pharmacies as well as those involving agricultural or veterinary use were also excluded. The studies which did not follow the structured standardized survey methodology employed by the European Centre of 
Disease Prevention and Control (ECDC), Global PPS or related research methods were also subsequently excluded [33].

\subsection{Data extraction and analyses}

Extraction and analysis of data were in line with the Preferred Reporting Item for Systematic Review and Metaanalysis (PRISMA).Core points of these research papers were prearranged including the date of survey, antimicrobial use prevalence, the most common antimicrobials prescribed and indications among children and the adult population throughout different regions of the world. All the relevant data regarding the use of antibiotics as per Anatomical Therapeutic Chemical (ATC) classification of antibiotics were retrieved [34]. In addition, the quantitative data concerning the number of patients administered antibiotics for the prophylaxis or treatment was also extracted.

Studies were classified according to their PPS method and protocol. Countries were classified according to the United Nations Region methodology and World Bank classification by income. For each geographical region, point prevalence surveys of antimicrobial use were pooled to analyze the frequency of use in children and adults for comparative purposes. Most of the time when adults and children were presented together, the proportion of children was typically very small. In this situation, the whole hospital (adults and children) together was documented as adults only. We also compared our findings with those from the recent EU/ EEA and Global PPS studies for these key indicators to add robustness to our findings $[25,31]$.

\section{Results:}

We identified 2,893 potentially pertinent research papers based on title and abstract. Finally, 60 articles, 17 studies covering children and 43 covering adult populations met the inclusion criteria and were incorporated into this systematic review (Figure 1). The included studies were from Asia (5 children \& 13 adults), Africa (1 child, 6 adults), Oceania ( 1 child $\& 3$ adults), America ( 1 child $\& 3$ adults), Europe ( 7 children $\& 17$ adults) and worldwide surveys ( 2 children \& 1 adult). These 60 surveys covered 4,235 health care settings worldwide (508 children \& 3,727 adult settings). Most of the PPS were conducted in upper-middle and high-income countries, and most of the studies were published after 2015 in Asian and African countries.

Table 1 and Table 2 summarize the reported number of patients on antimicrobials in different regions of the world as well as key findings by type of healthcare setting split into adults and children. The most frequently used 
antibiotics were the third-generation cephalosporins. Respiratory tract infections were typically the most common reason for prescribing antimicrobials. Among all identified regions around the globe, India was the region where the highest use of antimicrobials was seen among in-patients at 98.4\% [35]. The prescribing of antimicrobials for prophylaxis was also found to be the highest (71.0\%) in this study in India involving neonatal and pediatric patients [35]. The average number of antimicrobials prescribed per admitted patient was found to be highest in Kenya at 3.6 [36]. Table 3 consolidates the prevalence of antimicrobial use among in-patients by region.

\subsection{Antimicrobial Use in Children:}

Among children, India was the country where the highest use of antimicrobials was seen in two published studies reaching $98.4 \%[35,37]$. Ghana was the second-highest country at $70.6 \%$, China the third $(67.8 \%)$ and Turkey the fourth-highest country at $54.6 \%$ respectively [38-40]. Among 31 hospitals in the USA, the reported use of antimicrobials was $54.4 \%$ with gentamicin was most commonly used antibiotic followed by ampicillin and vancomycin [41]. The antimicrobial use rate was $46.0 \%$ in a survey conducted in Australia [42]. Among European countries, highest prevalence of antimicrobial use was found in hospitals in the UK followed by Italy. In the 2008 ESAC survey, which was based on pediatric antimicrobial prescribing in 32 hospitals among 21 European countries, the antimicrobial use rate was $32.4 \%$ with the most commonly used antibiotics for therapeutic use being the thirdgeneration cephalosporins (18\%), aminoglycosides (14\%) and extended-spectrum penicillin (10\%) [43]. Data from 2 hospitals of Germany and Croatia in 2005 showed antibiotic use at 17.4\% among the pediatric population [44], which is also the lowest use compared to other regions of the world.

\subsection{Antimicrobial Use in Adults:}

Among all the identified regions worldwide, the highest use of antimicrobials among countries and regions was seen in Pakistan (77.6\%) which recorded the highest use of ceftriaxone [45]. At the hospital level, China was the second country where the highest use of antimicrobials was seen (75.3\%) among all patients admitted onto different wards [46], with the findings already leading to strategies to try and address overuse of antimicrobials $[47,48]$. Botswana was the third and Nigeria was fourth-highest country at $70.6 \%$ and $69.7 \%$ respectively $[49,50]$. The fifth country with the highest use of antimicrobials was the Congo with an overall $68.0 \%$ usage among eleven different hospitals [51]. More than half of the patients were on antimicrobial use in hospital settings of Kenya (54.7\% and 67.7\%), Hubei province of China (55.6\%), Italy (51.1\%), and Singapore (51.0\%) [22, 36, 52-54]. Among 183 hospitals in the USA, the reported use of antimicrobials was $50 \%$ where vancomycin was most commonly used antibiotics 
followed by ceftriaxone and piperacillin plus tazobactam to treat different infections [55]. The Global PPS conducted among 335 hospitals across 53 countries found overall antibiotic use at $34.4 \%$ [25]. Antimicrobial use was highest among the African countries taking part at 50.0\% of inpatients and lowest in Eastern Europe at 27.4\% of patients [25].. Among European countries, the highest prevalence of antimicrobial use was found in Italy (51.1\%) [2]. Zarb et al., also found extensive use of antibiotics (34.6\%) in a study performed during 2010 across hospital settings among twenty-three European countries [23], while in 2009 from 172 hospitals across twenty-five European countries antibiotic utilization was lower at $29.0 \%$ [56]. More recently, Plachouras et al found an average rate of $30.5 \%$ among 1209 hospitals in $28 \mathrm{EU} / \mathrm{EEA}$ countries [31]. Among all the identified regions worldwide, antimicrobial use was lowest among patients in a hospital of Norway (16.6\%) [57].

\section{Discussion:}

To date, we believe this is the first systematic review that has fully scrutinized the research articles published on the use of antibiotics in acute care settings using the point prevalence method across countries and regions, building on the Pan-European (ECDC) and Global PPS studies [23,2531,43]. We again found considerable regional variation in antimicrobial prescribing among hospitalized patients (Tables 1 to 3), which could be due to a number of factors. These include differences in underlying infection rates, concerns with an accurate diagnosis, differences in resistance patterns, lack of standard treatment guidelines (STGs) within facilities and their use to guide rational prescribing, differences in the monitoring of antibiotic use especially against agreed guidelines, lack of infection and control procedures, overcrowding on wards, as well as extending prophylactic use of antibiotics with concerns with air and hygiene quality in operating theatres and hygiene on the wards $[3,25,50,91-98]$. This systematic review exposed the fact that most PPS studies of antimicrobial use are principally conducted among European countries. There have only been a limited number of PPS studies undertaken to date in Africa to date despite the high burden of infectious diseases; however, this is beginning to change with recent studies in for instance Ghana, Nigeria and Zimbabwe in addition to those listed in Table 1 and the 5 countries taking part in the Global PPS study [25, 99-103]. Despite considerable research papers documenting the trend of antimicrobial use and potential adverse events, PPS studies from Asian countries are also scarcer than seen in Europe (Table 1) including Asian countries taking part in the Global PPS study [25].

The domination of third-generation cephalosporin and fluoroquinolones use among all regions in our study suggests substantial use of broad-spectrum antimicrobials across countries. This mirrors the high use of third-generation 
cephalosporin, fluoroquinolones and carbapenam in the Global PPS [25]; however different to the recent EU/ EEA study where penicillins with beta-lactamase inhibitors were the most used antimicrobials [31]. Excessive use broad spectrum antibiotics may reflect high AMR rates and/ or the emergence of multidrug-resistant microbes coupled with a lack of culture and sensitivity analysis facilities and available STGs $[17,19,98,100,104-106]$. Extensive broadspectrum antimicrobial prescribing could be explained by regionally high rates of carbapenem-resistant or Gramnegative extended-spectrum beta-lactamase-producing organisms [107-109]. We have seen that among American nations, surveillance programs have identified an increase in carbapenem-resistant Klebsiella species and resistance to extended-spectrum cephalosporins, with a high prevalence of Klebsiella spp and ESBL-producing Escherichia coli with concerns also seen in Asia [110-114]. Consequently, programmes are needed in hospitals to reduce inappropriate antibiotic prescribing, which fuels rising AMR rates adding to morbidity, mortality and the cost of treatment $[9,10,12,13,22,51,85,115,116]$.

A current concern is that we saw limited regulation of antimicrobial use due either to missing guidelines or, more commonly due to lack of enforcement of current STGs among a number of countries including African countries as well as West and Central Asian countries taking part in the Global PPS [19,25,38,46,50,64,83,98]. There was also limited targeted use of antibiotics particularly in Africa as well as West and Central Asia in the Global PPS (14.6\% each) [25]. However, encouragingly we saw higher rates of compliance with local guidelines in other regions in the Global PPS study ranging from $64.1 \%$ in Latin America to $85.8 \%$ in North America where guidelines were available [25]. In addition, $76.3 \%$ of the hospitals in the recent EU/ EEA study reported the availability and use of antimicrobial guidelines [31]. There was also good guideline adherence among hospitals in Ghana and Namibia although below target rates of $95 \%$ compliance $[100,117]$. This is important since adherence to agreed STGs enhances the quality of antimicrobial prescribing $[25,50,118]$. The lack of guidelines as well as monitoring of antibiotic prescribing in hospitals may help explain the excessive use of broad-spectrum antimicrobials in this and other studies $[19,22,38,44,46,55,59,62,64,73,109,116]$. The process of rational antimicrobial prescribing is multifaceted supported by local patterns of antimicrobial susceptibility [4,50, 117-119-123]. In regions where antimicrobial susceptibility information is not available, the selection of antimicrobial is challenging even for experienced health care providers $[124,125]$. The practical differences in antimicrobial prescribing rates between the various countries and regions could be due to a number of factors including, as mentioned. cultural influences, national guidelines, local or regional policies, local resistance patterns, knowledge on rational antimicrobial use and the availability of antimicrobials in the 
market. In addition, the activities of pharmaceutical companies if this is the main source of physician information regarding potential antibiotics to prescribe [122,126-128]. For instance in sub-Saharan Africa, there can high rates of HIV, TB and malaria among admitted patients $[24,50]$, which are not seen in other regions. In addition, the implementation of infection prevention and control policies are typically stricter and monitored with greater instigation of antimicrobial stewardship programmes (ASPs) among European countries [31]. In Pakistan, patients are prone to acquire multidrug-resistant infectious disease and healthcare-associated infections $[7,94]$.

Typically the first step to address concerns with inappropriate prescribing of antibiotics in hospitals is the documentation of current utilization and sensitivity patterns to help develop pertinent local guidelines, and subsequently monitor prescribing against these guidelines $[117,121]$. This can be part of instigating ASPs in hospitals to reduce inappropriate prescribing [129-132]. However, this is more challenging in lower-and middle-income countries (LMICs) in view of resource, manpower and cultural issues resulting in variable implementation to date [9193, 133]. However, interventions to decrease irrational antimicrobial prescribing must be carefully handled so as not to restrict access to antimicrobials for patients with true bacterial disease as this can lead to therapeutic failure [134]. Increasing AMR rates and irrational use of antibiotics can potentially be avoided through clinical pharmacist interventions as part of ASPs within hospitals [1135].Improving the rational use of antibiotics will also help decrease adverse drug reactions (ADRs) with antimicrobials currently the second most common reason for ADRs in the USA [136]. Prior use of antimicrobials is also a threat to the growth of multidrug-resistant microbes [109,137], and this must be carefully handled through multiple interventions in ambulatory care to reduce inappropriate prescribing and dispensing of antibiotics alongside ASPs within hospitals [129-133,138-141]. Comparing trends of antimicrobial prescribing between countries and policies also allows key stakeholder groups to understand the wide range of patterns of antimicrobial use and subsequent concomitant resistance between them to develop appropriate strategies to reduce AMR as part of National Action Plans [4,16,138-140,142,].

We acknowledge our appraisal has limitations. A number of possible confounding and biasing parameters might have hindered this systematic review. The mixture of studies with diverse settings and heterogeneity in patients' characteristics hindered a standard systematic appraisal, and figures might not be representative of existing practices in the countries and the regions studied. Our systematic review was also restricted by the quality of research papers accessible for scrutiny as well as limitations intrinsic in our own techniques. For instance, we opted not to incorporate 
unpublished data on PPS, and so some degree publication bias may be reflected in our results. The difference in the quality of different countries' health-care systems and the definitions of infections also had a discernible influence on the systematic review. In addition, data on antimicrobial use ranges was not available in most papers and different papers mentioned the top three antibiotics at different levels of ATC classification as there was no standardized way of reporting prevalence and usage data. Another limitation that was beyond your control was that some PPS used only antibacterial agents some anti-infectives, some included a wider range of antimicrobials including those for TB. Finally, throughout this systematic review, we paid attention only to PPS of antimicrobial use. We acknowledge that PPS is not only a methodology to evaluate patterns of antimicrobial use but also seeking ways to improve future use by increasing documentation of key aspects of antimicrobial use including documenting the rationale for their use, start and stop dates, and any missed doses. Nevertheless, we brought into play a broad series of search terms concerning PPS and consequently we presuppose that the terms should spot those research papers covering PPS. Having said this, we believe the strong points of this review include the inclusive search approach and the quality assessment of PPS methodology. In addition, the ability to compare and contrast findings between different countries and regions to provide a basis for the future especially in countries where there are currently concerns with high inappropriate antibiotic use. Consequently, we are confident in our findings.

\section{CONCLUSION}

In conclusion, we believe PPS is a useful tool to assess the patterns of antimicrobial use within hospitals and across countries and regions, and provides a robust baseline for developing pertinent quality improvement programmes. This is especially important in regions such as Africa where there has been a paucity of PPS studies compared with Europe. However, we believe a standardized surveillance method is needed building on the Global PPS initiative. Another concern is that the prevalence of antimicrobial use is significantly higher among non-European hospitals compared with European hospitals, which can be a serious risk factor for resistance development. In order to optimize antimicrobial use in the future, more efforts are required especially in LMICs to improve diagnosis and management including the instigation of STGs based on local resistance patterns as well as monitoring prescribing against agreed guidelines and quality indicators. Continued comparisons between countries alongside the evaluation of the impact of different initiatives will help countries to improve their antibiotic utilization and reduce future AMR rates. We will be monitoring this in the future. 


\section{Financial support}

No financial support was provided.

\section{Transparency declarations}

The authors declare that there are no actual or potential conflicts of interest in relation to this article.

\section{References:}

1. Alharbi SA, Wainwright M, Alahmadi TA, Salleeh HB, Faden AA, Chinnathambi A. What if Fleming had not discovered penicillin? Saudi journal of biological sciences, 21(4), 289-93 (2014).

2. Laxminarayan R, Matsoso P, Pant S et al. Access to effective antimicrobials: a worldwide challenge. The Lancet, 387(10014), 168-75 (2016).

3. Md Rezal RS, Hassali MA, Alrasheedy AA, Saleem F, Md Yusof FA, Godman B. Physicians' knowledge, perceptions and behaviour towards antibiotic prescribing: a systematic review of the literature. Expert review of anti-infective therapy, 13(5), 665-80 (2015).

4. Godman B, Fadare J, Kibuule D et al. Initiatives Across Countries to Reduce Antibiotic Utilisation and Resistance Patterns: Impact and Implications. In: Drug Resistance in Bacteria, Fungi, Malaria, and Cancer. Springer, 539-76 (2017).

5. Van Nguyen K, Do NTT, Chandna A et al. Antibiotic use and resistance in emerging economies: a situation analysis for Viet Nam. BMC public health, 13(1), 1158 (2013).

6. Bell BG, Schellevis F, Stobberingh E, Goossens H, Pringle M. A systematic review and meta-analysis of the effects of antibiotic consumption on antibiotic resistance. BMC Infectious Diseases. 14(1), 13 (2014)

7. Saleem Z, Hassali MA. Travellers take heed: Outbreak of extensively drug resistant (XDR) typhoid fever in Pakistan and a warning from the US CDC. Travel Medicine and Infectious Disease, 27, 124 (2018).

8. Laxminarayan R, Duse A, Wattal C et al. Antibiotic resistance-the need for global solutions. The Lancet infectious diseases, 13(12), 1057-98 (2013).

9. Cassini A, Hogberg LD, Plachouras D et al. Attributable deaths and disability-adjusted life-years caused by infections with antibiotic-resistant bacteria in the EU and the European Economic Area in 2015: a population-level modelling analysis. The Lancet. Infectious diseases, 19(1), 56-66 (2019).

10. Founou RC, Founou LL, Essack SY. Clinical and economic impact of antibiotic resistance in developing countries: A systematic review and meta-analysis. PloS one, 12(12), e0189621 (2017).

11. OECD Health Policy Studies, Stemming the Superbug Tide. Available at URL: https://www.oecdilibrary.org/sites/9789264307599-en/index.html?itemId=/content/publication/9789264307599. en\&mimeType=text/html. (2018.).

12. Hofer U. The cost of antimicrobial resistance. Nature reviews. Microbiology, 17(1), 3 (2019).

13. O'Neill J. Antimicrobial Resistance: Tackling a crisis for the health and wealth of nations. The Review on Antimicrobial Resistance. Available at URL: https://amr review.org/sites/default/files/AMR\%20Review\%20Paper\%20 $\% 20$ Tackling $\% 20 \mathrm{a} \% 20$ crisis $\% 20$ for $\% 20$ the $\% 20$ health $\% 20$ and $\% 20$ wealth $\% 20$ of $\% 20$ nations_1.pdf.). (2014)

14. World Health Organization. Global action plan on antimicrobial resistance. Available at URL: http://www.who.int/antimicrobial-resistance/publications/global-action-plan/en/ (2015)

15. World Health Organization WH. World Health Assembly addresses antimicrobial resistance, immunization gaps and malnutrition. Available at URL: http:/www.who.int/mediacentre/news/releases/2015/wha-25may-2015/en/ (2015)

16. Saleem Z, Hassali MA, Hashmi FK. Pakistan's national action plan for antimicrobial resistance: translating ideas into reality. The Lancet Infectious Diseases, 18(10), 1066-67 (2018).

*Documenting the NAP of Pakistan

17. Jinks T, Lee N, Sharland M et al. A time for action: antimicrobial resistance needs global response. Bulletin of the World Health Organization, 94(8), 558-558A (2016).

18. Boucher HW, Bakken JS, Murray BE. The United Nations and the Urgent Need for Coordinated Global Action in the Fight Against Antimicrobial Resistance Coordinated Global Action to Fight Against Antimicrobial Resistance. Annals of internal medicine, 165(11), 812-13 (2016). 
19. Versporten A, Bielicki J, Drapier N et al. The Worldwide Antibiotic Resistance and Prescribing in European Children (ARPEC) point prevalence survey: developing hospital-quality indicators of antibiotic prescribing for children. Journal of Antimicrobial Chemotherapy, 71(4), 1106-17 (2016).

20. Woodward M. Epidemiology: study design and data analysis (CRC press, 2013).

21. Aldeyab MA, Kearney MP, McElnay JC et al. A point prevalence survey of antibiotic prescriptions: benchmarking and patterns of use. British journal of clinical pharmacology, 71(2), 293-296 (2011).

22. Xie D-s, Xiang L-1, Li R, Hu Q, Luo Q-q, Xiong W. A multicenter point-prevalence survey of antibiotic use in 13 Chinese hospitals. Journal of infection and public health, 8(1), 55-61 (2015).

23. Zarb P, Coignard B, Griskeviciene J et al. The European Centre for Disease Prevention and Control (ECDC) pilot point prevalence survey of healthcare-associated infections and antimicrobial use. Euro Surveill, 17(46), 20316 (2012).

24. Massele A, Tiroyakgosi C, Matome $\mathrm{M}$ et al. Research activities to improve the utilization of antibiotics in Africa. Expert review of pharmacoeconomics \& outcomes research, 17(1), 1-4 (2017).

25. Versporten A, Zarb P, Caniaux I et al. Antimicrobial consumption and resistance in adult hospital inpatients in 53 countries: results of an internet-based global point prevalence survey. The Lancet. Global health, 6(6), e619-29 (2018).

**Current results of the Global PPS study used for comparative purposes

26. Van Boeckel TP, Gandra S, Ashok A et al. Global antibiotic consumption 2000 to 2010: an analysis of national pharmaceutical sales data. The Lancet Infectious Diseases, 14(8), 42-750 (2014).

27. Marquet K, Liesenborgs A, Bergs J, Vleugels A, Claes N. Incidence and outcome of inappropriate inhospital empiric antibiotics for severe infection: a systematic review and meta-analysis. Critical Care, 19(1), 63 (2015).

28. Morgan DJ, Okeke IN, Laxminarayan R, Perencevich EN, Weisenberg S. Non-prescription antimicrobial use worldwide: a systematic review. The Lancet infectious diseases, 11(9), 692-701 (2011).

29. Keller SC, Tamma PD, Cosgrove SE et al. Ambulatory antibiotic stewardship through a human factors engineering approach: a systematic review. The Journal of the American Board of Family Medicine, 31(3), 417-30 (2018).

30. Costelloe C, Metcalfe C, Lovering A, Mant D, Hay AD. Effect of antibiotic prescribing in primary care on antimicrobial resistance in individual patients: systematic review and meta-analysis. Bmj, 340, c2096 (2010).

31. Plachouras D, Karki T, Hansen S et al. Antimicrobial use in European acute care hospitals: results from the second point prevalence survey (PPS) of healthcare-associated infections and antimicrobial use, 2016 to 2017. Euro surveillance : bulletin Europeen sur les maladies transmissibles $=$ European communicable disease bulletin, 23(46) (2018).

32. Zarb P, Goossens H. European Surveillance of Antimicrobial Consumption (ESAC): value of a pointprevalence survey of antimicrobial use across Europe. Drugs. 71(6):745-55 (2011)

33. Ansari F, Erntell M, Goossens H, Davey P, Group EIHCS. The European surveillance of antimicrobial consumption (ESAC) point-prevalence survey of antibacterial use in 20 European hospitals in 2006. Clinical infectious diseases, 49(10), 1496-1504 (2009).

34. WHO. WHO Collaborating Centre for Drug Statistics Methodology. ATC/ DDD Index. Available at URL: https://www.whocc.no/

35. Singh S, Jose $\mathrm{T}$, Versporten A et al. A point prevalence surveillance study from pediatric and neonatal specialty hospitals in India. Journal of Pediatric Infectious Diseases, 9(3), 151-55 (2014).

36. Momanyi L, Opanga S, Nyamu D, Oluka M, Kurdi A, Godman B. Antibiotic prescribing patterns at a leading referral hospital in Kenya: a point prevalence survey. Journal of Research in Pharmacy Practice, 8(3), 149. (2019).

37. Gandra S, Singh SK, Jinka DR et al. Point Prevalence Surveys of Antimicrobial Use among Hospitalized Children in Six Hospitals in India in 2016. 6(3) (2017).

38. Ceyhan M, Yildirim I, Ecevit C et al. Inappropriate antimicrobial use in Turkish pediatric hospitals: a multicenter point prevalence survey. International Journal of Infectious Diseases, 14(1), e55-e61 (2010).

39. Labi A-K, Obeng-Nkrumah N, Sunkwa-Mills G et al. Antibiotic prescribing in paediatric inpatients in Ghana: a multi-centre point prevalence survey. BMC pediatrics, 18(1), 391 (2018).

40. Zhang J-S, Liu G, Zhang W-S et al. Antibiotic usage in Chinese children: a point prevalence survey. World Journal of Pediatrics, 14(4), 335-43 (2018). 
41. Grohskopf LA, Huskins WC, Sinkowitz-Cochran RL, Levine GL, Goldmann DA, Jarvis WR. Use of antimicrobial agents in United States neonatal and pediatric intensive care patients. Pediatric Infectious Disease Journal, 24(9), 766-73 (2005).

42. Osowicki J, Gwee A, Noronha J et al. Australia-wide point prevalence survey of the use and appropriateness of antimicrobial prescribing for children in hospital. The Medical Journal of Australia, 201(11), 657-62 (2014).

43. Amadeo B, Zarb P, Muller A et al. European Surveillance of Antibiotic Consumption (ESAC) point prevalence survey 2008: paediatric antimicrobial prescribing in 32 hospitals of 21 European countries. Journal of antimicrobial chemotherapy, dkq309 (2010).

44. Ufer M, Radosević N, Vogt A et al. Antimicrobial drug use in hospitalised paediatric patients: a crossnational comparison between Germany and Croatia. Pharmacoepidemiology and drug safety, 14(10), 73539 (2005).

45. Saleem Z, Hassali MA, Versporten A et al. A multicenter point prevalence survey of antibiotic use in Punjab, Pakistan: findings and implications. Expert review of anti-infective therapy, 17(4), 285-93 (2019).

* First comprehensive PPS in Pakistan

46. Ren N, Zhou P, Wen X et al. Point prevalence survey of antimicrobial use in Chinese hospitals in 2012. American journal of infection control, 44(3), 332-39 (2016).

47. Zou X-x, Fang Z, Min R et al. Is nationwide special campaign on antibiotic stewardship program effective on ameliorating irrational antibiotic use in China? Study on the antibiotic use of specialized hospitals in China in 2011-2012. Journal of Huazhong University of Science and Technology [Medical Sciences], 34(3), 456-63 (2014).

48. Hou D, Wang Q, Jiang C, Tian C, Li H, Ji B. Evaluation of the short-term effects of antimicrobial stewardship in the intensive care unit at a tertiary hospital in China. PloS one, 9(7), e101447 (2014).

49. Oduyebo O, Olayinka A, Iregbu $\mathrm{K}$ et al. A point prevalence survey of antimicrobial prescribing in four Nigerian Tertiary Hospitals. Annals of Tropical Pathology, 8(1), 42 (2017).

50. Anand Paramadhas BD, Tiroyakgosi C, Mpinda-Joseph P et al. Point prevalence study of antimicrobial use among hospitals across Botswana; findings and implications. Expert review of anti-infective therapy, 17(7), 535-46 (2019).

51. Wambale J, Mulwahali e, Iyamba J-ML, Mathe DM, Kavuo SK. Point prevalence study of antibiotic use in hospitals in Butembo. International Journal of Medicine and Medical Sciences, 8(12), 133-39 (2016).

52. Antonioli P, Manzalini MC, Stefanati A et al. Temporal trends of healthcare associated infections and antimicrobial use in 2011-2013, observed with annual point prevalence surveys in Ferrara University Hospital, Italy. Journal of Preventive Medicine and Hygiene, 57(3), E135 (2016).

53. Cai Y, Venkatachalam I, Tee NW et al. Prevalence of healthcare-associated infections and antimicrobial use among adult inpatients in Singapore acute-care hospitals: Results from the first national point prevalence survey. Clinical Infectious Diseases, 64, S61-S67 (2017).

54. Okoth C, Opanga S, Okalebo F, Oluka M, Baker Kurdi A, Godman B. Point prevalence survey of antibiotic use and resistance at a referral hospital in Kenya: findings and implications. Hospital Practice, 1-9 (2018).

55. Magill SS, Edwards JR, Beldavs ZG et al. Prevalence of antimicrobial use in US acute care hospitals, MaySeptember 2011. Jama, 312(14), 1438-46 (2014).

56. Zarb P, Amadeo B, Muller A et al. Identification of targets for quality improvement in antimicrobial prescribing: the web-based ESAC Point Prevalence Survey 2009. Journal of Antimicrobial Chemotherapy, 66(2), 443-49 (2011).

57. Berild D, Ringertz SH, Lelek M. Appropriate antibiotic use according to diagnoses and bacteriological findings: report of 12 point-prevalence studies on antibiotic use in a university hospital. Scandinavian journal of infectious diseases, 34(1), 56-60 (2002).

58. Soltani J, Pouladfar G, Versporten A et al. Point prevalence survey of antimicrobial prescription and infection in pediatric and neonatal wards of two Iranian teaching hospitals. Erciyes Medical Journal/Erciyes Tip Dergisi, 41(1), 25-32 (2019).

59. Hajdu A, Samodova O, Carlsson T et al. A point prevalence survey of hospital-acquired infections and antimicrobial use in a paediatric hospital in north-western Russia. Journal of Hospital Infection, 66(4), 378384 (2007).

60. Gharbi M, Doerholt K, Vergnano S et al. Using a simple point-prevalence survey to define appropriate antibiotic prescribing in hospitalised children across the UK. BMJ open, 6(11), e012675 (2016).

61. Ang L, Laskar R, Gray J. A point prevalence study of infection and antimicrobial use at a UK children's hospital. Journal of Hospital Infection, 68(4), 372-74 (2008). 
62. Sviestina I, Mozgis D. Antimicrobial usage among hospitalized children in Latvia: A neonatal and pediatric antimicrobial point prevalence survey. Medicina, 50(3), 175-81 (2014).

63. De Luca M. Antibiotic Prescriptions and Prophylaxis in Italian Children. Is It Time to Change? Data from the ARPEC Project. European journal of clinical microbiology \& infectious diseases 11(5), e0154662 (2016).

62.

64. Versporten A, Sharland M, Bielicki J, Drapier N, Vankerckhoven V, Goossens H. The antibiotic resistance and prescribing in European Children project: a neonatal and pediatric antimicrobial web-based point prevalence survey in 73 hospitals worldwide. The Pediatric infectious disease journal, 32(6), e242-53 (2013).

65. Morioka H, Nagao M, Yoshihara S et al. The first multi-centre point-prevalence survey in four Japanese university hospitals. Journal of Hospital Infection, 99(3), 325-31 (2018).

66. Morioka H, Hirabayashi A, Iguchi M et al. The first point prevalence survey of health care-associated infection and antimicrobial use in a Japanese university hospital: A pilot study. American journal of infection control, 44(7), e119-23 (2016).

67. Saleem Z, Hassali MA, Hashmi FK, Godman B, Bhutta OA. A repeated point prevalence survey of antimicrobial use in specialized cancer care hospital of Pakistan: findings and implications. Hospital Practice, 47(3), 149-54 (2019).

68. Sheng T, Wijayaratne GB, Dabrera TM et al. Point-prevalence study of antimicrobial use in public hospitals in southern Sri Lanka identifies opportunities for improving prescribing practices. Infection Control \& Hospital Epidemiology, 40(2), 224-27 (2019).

69. Singh SK, Sengupta S, Antony R et al. Variations In Antibiotic Use Across India-Multicentre Study Through Global Point Prevalence Survey. Journal of Hospital Infection, 103(3), 280-83 (2019).

70. Nair MGV, Sharma SCD, Sahni BAK et al. Antimicrobial use and antimicrobial resistance in nosocomial pathogens at a tertiary care hospital in Pune. Medical Journal Armed Forces India, 71(2), 112-19 (2015).

71. Hammuda A, Hayder S, Elazzazy S, Black E. Point prevalence survey of antimicrobial utilization in oncology patients. Journal of infection in developing countries, 7(12), 990-93 (2013).

72. Al Matar M, Enani M, Binsaleh $\mathrm{G}$ et al. Point prevalence survey of antibiotic use in 26 Saudi hospitals in 2016. Journal of infection and public health, 12(1), 77-82 (2019).

73. Usluer G, Ozgunes I, Leblebicioglu H. A multicenter point-prevalence study: antimicrobial prescription frequencies in hospitalized patients in Turkey. Annals of clinical Microbiology and Antimicrobials, 4(1), 16 (2005).

74. Dlamini NN, Meyer JC, Kruger D, Kurdi A, Godman B, Schellack N. Feasibility of using point prevalence surveys to assess antimicrobial utilisation in public hospitals in South Africa: a pilot study and implications. Hospital practice, 47(2), 88-95 (2019).

75. Cotta M, Robertson M, Upjohn L, Marshall C, Liew D, Buising K. Using periodic point- prevalence surveys to assess appropriateness of antimicrobial prescribing in Australian private hospitals. Internal medicine journal, 44(3), 240-6 (2014).

76. Ingram P, Seet J, Budgeon C, Murray R. Point- prevalence study of inappropriate antibiotic use at a tertiary Australian hospital. Internal medicine journal, 42(6), 719-21 (2012).

77. Ho L, Melvani S. Serial Point- Prevalence Studies to Investigate Hospital Antimicrobial Prescribing. Journal of Pharmacy Practice and Research, 37(3), 190-3 (2007).

78. Lee C, Walker SA, Daneman N et al. Point prevalence survey of antimicrobial utilization in a Canadian tertiary-care teaching hospital. Journal of epidemiology and global health, 5(2), 143-50 (2015).

79. Black E, Neville H, Losier M et al. Antimicrobial Use at Acute Care Hospitals in Nova Scotia: A Point Prevalence Survey. The Canadian journal of hospital pharmacy, 71(4), 234-42 (2018).

80. Seaton R, Nathwani D, Burton P et al. Point prevalence survey of antibiotic use in Scottish hospitals utilising the Glasgow Antimicrobial Audit Tool (GAAT). International journal of antimicrobial agents, 29(6), 693-9 (2007).

81. Al-Taani GM, Scott M, Farren D et al. Longitudinal point prevalence survey of antibacterial use in Northern Ireland using the European Surveillance of Antimicrobial Consumption (ESAC) PPS and GlobalPPS tool. Epidemiology and infection, 146(8) 1-6 (2018).

82. Aldeyab M, Kearney M, McElnay J et al. A point prevalence survey of antibiotic use in four acute-care teaching hospitals utilizing the European Surveillance of Antimicrobial Consumption (ESAC) audit tool. Epidemiology \& Infection, 140(9), 1714-20 (2012). 
83. Robert J, Pean Y, Varon E et al. Point prevalence survey of antibiotic use in French hospitals in 2009. Journal of antimicrobial chemotherapy, dkr571 (2012).

84. Hansen S, Sohr D, Piening B et al. Antibiotic usage in German hospitals: Results of the second national prevalence study. Journal of Antimicrobial Chemotherapy, 68(12), 2934-9 (2013).

85. Lusignani LS, Blacky A, Starzengruber P, Diab-Elschahawi APM, Wrba DIT, Presterl E. A national point prevalence study on healthcare-associated infections and antimicrobial use in Austria. Wiener klinische Wochenschrift, 128(3-4), 89-94 (2016).

86. Akhloufi H, Streefkerk RH, Melles DC et al. Point prevalence of appropriate antimicrobial therapy in a Dutch university hospital. European Journal of Clinical Microbiology and Infectious Diseases, 34(8), 1631-7 (2015).

87. Willemsen I, Van Der Kooij T, Van Benthem B, Wille J, Kluytmans J. Appropriateness of antimicrobial therapy: a multicentre prevalence survey in the Netherlands, 2008-2009. Eurosurveillance, 15(46), 19715 (2010).

88. Krasniqi S, Versporten A, Jakupi A et al. Antibiotic utilisation in adult and children patients in Kosovo hospitals. Eur J Hosp Pharm, 26(3), 146-151 (2017).

89. Stefkovicova M, Litvova S, Melus V, Kristufkova Z, Brazinova A. Point prevalence study of antimicrobial usage in acute care hospitals in the Slovak Republic. J Hosp Infect, 93(4), 403-9 (2016).

90. Vlahović $\square$ Palčevski V, Dumpis U, Mitt P et al. Benchmarking antimicrobial drug use at university hospitals in five European countries. Clinical microbiology and infection, 13(3), 277-83 (2007).

91. Cox JA, Vlieghe E, Mendelson $\mathrm{M}$ et al. Antibiotic stewardship in low- and middle-income countries: the same but different? Clinical microbiology and infection, 23(11), 812-8 (2017).

92. Fadare JO, Ogunleye O, Iliyasu G, Adeoti A, Schellack N, Engler D, et al. Status of antimicrobial stewardship programmes in Nigerian tertiary healthcare facilities: Findings and implications. Journal of global antimicrobial resistance. 17:132-6 (2018)

93. Kalungia AC, Mwambula H, Munkombwe D, Marshall S, Schellack N, May C, et al. Antimicrobial stewardship knowledge and perception among physicians and pharmacists at leading tertiary teaching hospitals in Zambia: implications for future policy and practice. Journal of chemotherapy. 31(7-8):378-87 (2019)

94. Saleem Z, Hassali MA, Godman B, Hashmi FK, Saleem F. A multicenter point prevalence survey of healthcare-associated infections in Pakistan: Findings and implications. Am J Infect Control, 47(4), 421-4 (2019).

95. Mwita JC, Souda S, Magafu M, Massele A, Godman B, Mwandri M. Prophylactic antibiotics to prevent surgical site infections in Botswana: findings and implications. Hospital practice. 46(3):97-102 (2018)

96. Mpinda-Joseph P, Anand Paramadhas BD, Reyes G, Maruatona MB, Chise M, Monokwane-Thupiso BB, et al. Healthcare-associated infections including neonatal bloodstream infections in a leading tertiary hospital in Botswana. Hospital practice. 47(4):203-10 (2019)

97. Labi AK, Obeng-Nkrumah N, Owusu E, Bjerrum S, Bediako-Bowan A, Sunkwa-Mills G, et al. Multi-centre pointprevalence survey of hospital-acquired infections in Ghana. J Hosp Infect. 101(1):60-8 (2019)

98. Yevutsey SK, Buabeng KO, Aikins M, Anto BP, Biritwum RB, Frimodt-Moller N, et al. Situational analysis of antibiotic use and resistance in Ghana: policy and regulation. BMC public health. 17(1):89 (2017)

99. The first point-prevalence survey in different hospital settings in Zimbabwe. MTAPURI-ZINYOWERA S, MADZIKWA N, NDHLOVU M, CHAIBVA B, HOVE R, ROBERTSON V. MURIA 3;8 (2017). Available at URL: http://muria.mandela.ac.za/muria/media/Store/documents/Abstract\%20book\%20\%20MURAI\%203/MURIA3-AbstractBook-July-2017.pdf.).

100. AFRIYIE DK, SEFAH IA, SNEDDON J, MALCOM W, McKinney R, COOPER L et al. Antimicrobial Point Prevalence Surveys in two Ghanaian hospitals: opportunities for antimicrobial stewardship. JAC Antimicrob Resist. 1-9 (2020)

101. Abubakar U. Antibiotic use among hospitalized patients in northern Nigeria: a multicenter point-prevalence survey. BMC Infect Dis. 20(1):86 (2020)

102. Kiguba R, Karamagi C, Bird SM. Extensive antibiotic prescription rate among hospitalized patients in Uganda: but with frequent missed-dose days. The Journal of antimicrobial chemotherapy. 71(6):1697-70 (2016)

103. Labi A-K, Obeng-Nkrumah N, Nartey ET, Bjerrum S, Adu-Aryee NA, Ofori-Adjei YA, et al. Antibiotic use in a tertiary healthcare facility in Ghana: a point prevalence survey. Antimicrobial Resistance and Infection Control. 7:15 (2018) 
104. Gould I. Antibiotic resistance: the perfect storm. International journal of antimicrobial agents, 34, S2-S5 (2009).

105. Jean S-S, Hsueh P-R. High burden of antimicrobial resistance in Asia. International journal of antimicrobial agents, 37(4), 291-5 (2011).

106 Tadesse BT, Ashley EA, Ongarello S, Havumaki J, Wijegoonewardena M, Gonzalez IJ, et al. Antimicrobial resistance in Africa: a systematic review. BMC Infect Dis. 17(1):616 (2017)

107. Righi E, Peri AM, Harris PN et al. Global prevalence of carbapenem resistance in neutropenic patients and association with mortality and carbapenem use: systematic review and meta-analysis. Journal of Antimicrobial Chemotherapy, 72(3), 668-77 (2016).

108. Li DX, Cosgrove SE. Antimicrobial Stewardship: Efficacy and Implementation of Strategies to Address Antimicrobial Overuse and Resistance. Antimicrobial Stewardship, 2, 13 (2017).

109. Hawkey P. Multidrug-resistant Gram-negative bacteria: a product of globalization. Journal of Hospital Infection, 89(4), 241-247 (2015).

110. Jones RN, Guzman-Blanco M, Gales AC et al. Susceptibility rates in Latin American nations: report from a regional resistance surveillance program (2011). The Brazilian journal of infectious diseases, 17(6), 672-81 (2013).

111. Bartoloni A, Pallecchi L, Riccobono E et al. Relentless increase of resistance to fluoroquinolones and expanded- spectrum cephalosporins in Escherichia coli: 20 years of surveillance in resource- limited settings from Latin America. Clinical Microbiology and Infection, 19(4), 356-61 (2013).

112. Shields RK, Nguyen MH, Chen L, Press EG, Potoski BA, Marini RV, et al. Ceftazidime-Avibactam Is Superior to Other Treatment Regimens against Carbapenem-Resistant Klebsiella pneumoniae Bacteremia. Antimicrobial agents and chemotherapy. 61(8):e00883-17 (2017)

113. Suay-García B, Pérez-Gracia MT. Present and Future of Carbapenem-resistant Enterobacteriaceae (CRE) Infections. Antibiotics. 8(3) (2019)

114. Effah CY, Sun T, Liu S, Wu Y. Klebsiella pneumoniae: an increasing threat to public health. Annals of Clinical Microbiology and Antimicrobials. 19(1):1 (2020)

115. Levy E, Swami S, Dubois S, Wendt R, Banerjee R. Rates and appropriateness of antimicrobial prescribing at an academic children's hospital, 2007-2010. Infection Control \& Hospital Epidemiology, 33(4), 346-53 (2012).

116. Phu VD, Wertheim HF, Larsson $\mathrm{M}$ et al. Burden of hospital acquired infections and antimicrobial use in Vietnamese adult intensive care units. PloS one, 11(1), e0147544 (2016).

117. Nakwatumbah S, Kibuule D, Godman B, Haakuria V, Kalemeera F, Baker A, et al. Compliance to guidelines for the prescribing of antibiotics in acute infections at Namibia's national referral hospital: a pilot study and the implications. Expert review of anti-infective therapy, 15(7):713-21 (2017)

118 Niaz Q, Godman B, Massele A, Campbell S, Kurdi A, Kagoya HR, et al. Validity of World Health Organisation prescribing indicators in Namibia's primary healthcare: findings and implications.

International journal for quality in health care. 31(5):338-45 (2019)

119. Lob SH, Hoban DJ, Sahm DF, Badal RE. Regional differences and trends in antimicrobial susceptibility of Acinetobacter baumannii. International journal of antimicrobial agents, 47(4), 317-23 (2016).

120. Sturm A, Van der Pol R, Smits A et al. Over-the-counter availability of antimicrobial agents, selfmedication and patterns of resistance in Karachi, Pakistan. Journal of Antimicrobial Chemotherapy, 39(4), 543-7 (1997).

121. Kalaba M, Kosutic J, Godman B, Radonjic V, Vujic A, Jankovic S, et al. Experience with developing antibiotic stewardship programs in Serbia: potential model for other Balkan countries? Journal of comparative effectiveness research. 7(3):247-58 (2018)

122 Nusrat T, Akter N, Rahman NAA, Godman B, DT DR, Haque M. Antibiotic resistance and sensitivity pattern of Metallo- $\beta$-Lactamase Producing Gram-Negative Bacilli in ventilator-associated pneumonia in the intensive care unit of a public medical school hospital in Bangladesh. Hospital practice EPrint (2020)

123. Zellweger RM, Carrique-Mas J, Limmathurotsakul D, Day NPJ, Thwaites GE, Baker S. A current perspective on antimicrobial resistance in Southeast Asia. The Journal of antimicrobial chemotherapy, 72(11):2963-72 (2017)

124. Okeke IN, Klugman KP, Bhutta ZA et al. Antimicrobial resistance in developing countries. Part II: strategies for containment. The Lancet infectious diseases, 5(9), 568-80 (2005).

125. Okeke IN, Laxminarayan R, Bhutta ZA et al. Antimicrobial resistance in developing countries. Part I: recent trends and current status. The Lancet infectious diseases, 5(8), 481-93 (2005). 
126. Riaz H, Godman B, Hussain S et al. Prescribing of bisphosphonates and antibiotics in Pakistan: challenges and opportunities for the future. Journal of Pharmaceutical Health Services Research, 6(2), 111-21 (2015).

127. Ogunleye OO, Fadare JO, Yinka-Ogunleye AF, Anand Paramadhas BD, Godman B. Determinants of antibiotic prescribing among doctors in a Nigerian urban tertiary hospital. Hospital practice (1995), 47(1), 53-8 (2019).

**Good study documenting the challenges with ASPs in LMICs

128. Sharmin R, Sharmin ZR, Md. Mosaddek AS, Islam MZ, Rahman MF, Parvin R, et al. Medicine promotional literature as a source of updated information in Bangladesh: Do those advertising literature promote continued medical education or deceptive advertising? Acta Med Int, 4:20-5 (2017)

129. Van Dijck C, Vlieghe E, Cox JA. Antibiotic stewardship interventions in hospitals in low-and middleincome countries: a systematic review. Bull World Health Organ, 96(4):266-80 (2018)

130. Honda H, Ohmagari N, Tokuda Y, Mattar C, Warren DK. Antimicrobial Stewardship in Inpatient Settings in the Asia Pacific Region: A Systematic Review and Meta-analysis. Clinical infectious diseases, 64(suppl_2):S119-s26 (2017)

131. Nathwani D, Varghese D, Stephens J, Ansari W, Martin S, Charbonneau C. Value of hospital antimicrobial stewardship programs [ASPs]: a systematic review. Antimicrobial resistance and infection control, 8:35 (2019)

132. Newton JA, Robinson S, Ling CLL, Zimmer L, Kuper K, Trivedi KK. Impact of Procalcitonin Levels Combined with Active Intervention on Antimicrobial Stewardship in a Community Hospital. Open Forum Infect Dis, 6(11) (2019)

133. Charani E, Smith I, Skodvin B, Perozziello A, Lucet J-C, Lescure F-X, et al. Investigating the cultural and contextual determinants of antimicrobial stewardship programmes across low-, middle- and high-income countries-A qualitative study. PloS one, 14(1):e0209847-e (2019)

134. Kollef MH, Micek ST. Rational use of antibiotics in the ICU: balancing stewardship and clinical outcomes. Jama, 312(14), 1403-1404 (2014).

135. Kotwani A, Wattal C, Joshi P, Holloway K. Irrational use of antibiotics and role of the pharmacist: an insight from a qualitative study in New Delhi, India. Journal of clinical pharmacy and therapeutics, 37(3), 308-12 (2012).

*Good study documenting the importance of pharmacist interventions with improving antibiotic use

136. Shehab N, Patel PR, Srinivasan A, Budnitz DS. Emergency department visits for antibiotic-associated adverse events. Clinical Infectious Diseases, 47(6), 735-43 (2008).

137. Prasad R, Gupta N, Singh M. Multidrug resistant tuberculosis: trends and control. Indian J Chest Dis Allied Sci, 56(4), 237-46. (2014).

138. Fürst J, Čižman M, Mrak J et al. The influence of a sustained multifaceted approach to improve antibiotic prescribing in Slovenia during the past decade: findings and implications. Expert review of anti-infective therapy, 13(2), 279-89 (2015).

139. Godman B, Haque M, McKimm J, Abu Bakar M, Sneddon J, Wale J, et al. Ongoing strategies to improve the management of upper respiratory tract infections and reduce inappropriate antibiotic use particularly among lower and middle-income countries: findings and implications for the future. Current medical research and opinion, 36(2):301-27 (2020)

140. Abilova V, Kurdi A, Godman B. Ongoing initiatives in Azerbaijan to improve the use of antibiotics; findings and implications. Expert review of anti-infective therapy, 16(1):77-84 (2018)

141. Alrasheedy AA, Alsalloum MA, Almuqbil FA, Almuzaini MA, Aba Alkhayl BS, Albishri AS, et al. The impact of law enforcement on dispensing antibiotics without prescription: a multi-methods study from Saudi Arabia. Expert review of anti-infective therapy, 18(1):87-9 (2020)

142. Goossens $\mathrm{H}$, Guillemot D, Ferech $\mathrm{M}$ et al. National campaigns to improve antibiotic use. European journal of clinical pharmacology, 62(5), 373-9 (2006). 


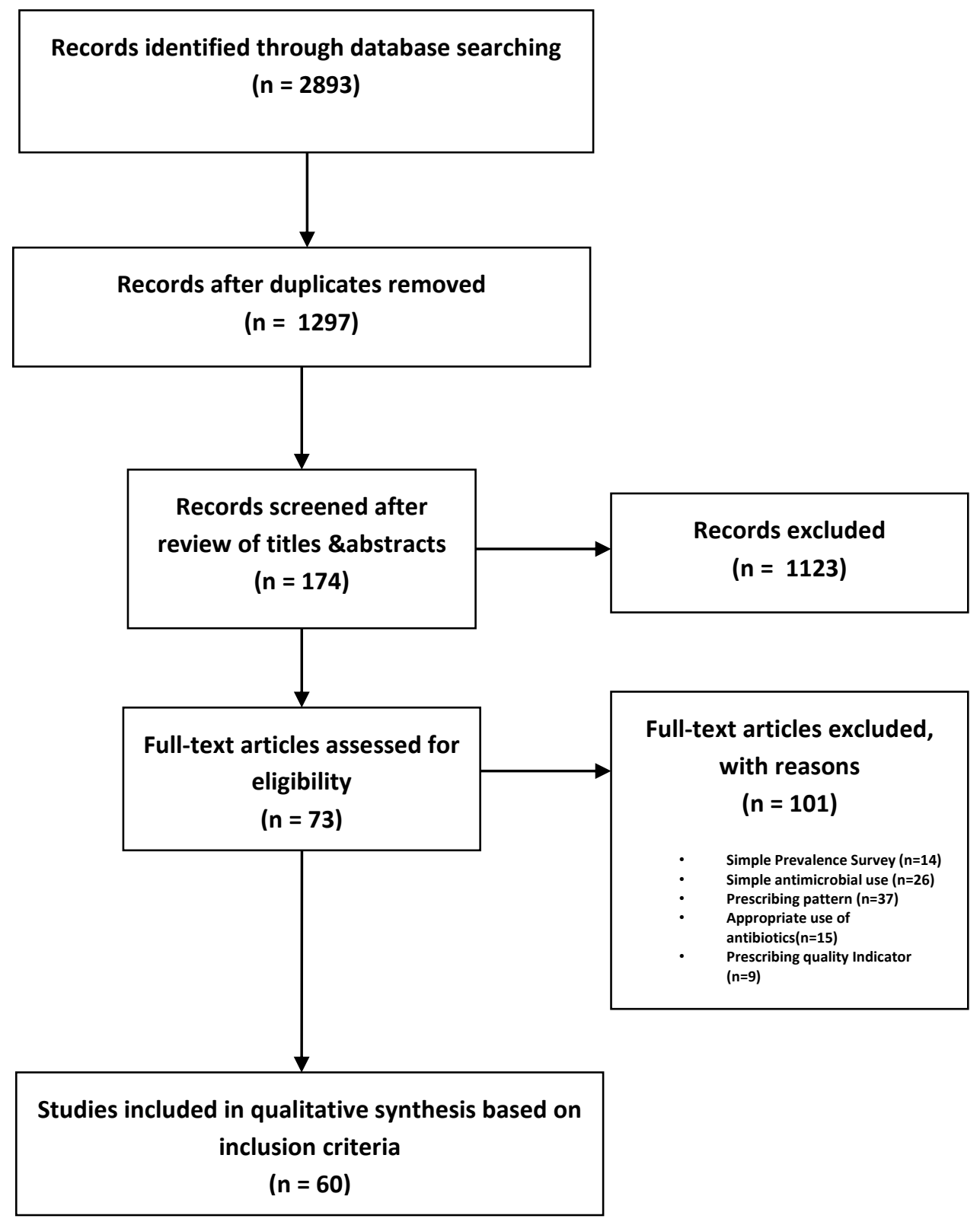

Figure 1: Flow Chart of Study Selection 
Table 1: Literature Review of Published Point-Prevalence Surveys (PPS) in Children

\begin{tabular}{|c|c|c|c|c|c|c|c|c|c|c|c|c|c|}
\hline $\begin{array}{l}\text { Continent and } \\
\text { Country }\end{array}$ & $\begin{array}{l}\text { World Bank } \\
\text { Classification } \\
\text { by income }{ }^{\#}\end{array}$ & $\begin{array}{l}\text { Author } \\
\text { Name \& } \\
\text { Date }\end{array}$ & $\begin{array}{l}\text { No. of } \\
\text { ACH }\end{array}$ & $\begin{array}{l}\text { PPS } \\
\text { Method }\end{array}$ & $\begin{array}{l}\text { PPS } \\
\text { Protocol }\end{array}$ & $\begin{array}{c}\text { Study } \\
\text { Duration }\end{array}$ & $\begin{array}{c}\text { Antimicrobial } \\
\text { use rate } \\
\text { n (\%) }\end{array}$ & $\begin{array}{l}\text { Drug.1 } \\
\text { ATC Code (\%) }\end{array}$ & $\begin{array}{l}\text { Drug.2 } \\
\text { ATC Code (\%) }\end{array}$ & $\begin{array}{l}\text { Drug.3 } \\
\text { ATC Code (\%) }\end{array}$ & $\begin{array}{l}\text { Prophylaxis } \\
(\%)\end{array}$ & $\begin{array}{l}\text { Treatment } \\
\text { (\%) }\end{array}$ & $\begin{array}{l}\text { Antimicrobials } \\
\text { (Drugs/Patient) }\end{array}$ \\
\hline \multicolumn{14}{|l|}{ Asia } \\
\hline Iran [58] & LM & $\begin{array}{l}\text { Soltani et al., } \\
2019 \\
\end{array}$ & 2 & Repeated & ARPEC & 2011-2012 & $252(64.0)$ & $\begin{array}{l}\text { Ceftriaxone } \\
\text { J0IDD04 (19.9) } \\
\end{array}$ & $\begin{array}{l}\text { Ampicillin- } \\
\text { JOICAOI (14.3) }\end{array}$ & $\begin{array}{l}\text { Vancomycin- } \\
\text { JOIXAOI (13.3) }\end{array}$ & 16.9 & 82.3 & $391(1.55)$ \\
\hline China [40] & UM & $\begin{array}{l}\text { Zhang et al., } \\
2018\end{array}$ & 18 & Period & GARPEC & $\begin{array}{l}\text { December } \\
\text { 2016- } \\
\text { February } 2017\end{array}$ & $975(67.8)$ & $\begin{array}{l}\text { Third-generation } \\
\text { cephalosporins- } \\
\text { JOIDD }\end{array}$ & $\begin{array}{l}\text { Beta lactum plus } \\
\text { beta lactum } \\
\text { inhibitors- } \\
\text { JOICR }\end{array}$ & - & - & - & $1238(1.27)$ \\
\hline $\begin{array}{l}\text { India [37] } \\
\end{array}$ & LM & $\begin{array}{l}\text { Gandra et al., } \\
2017\end{array}$ & 6 & Repeated & $\begin{array}{l}\text { GARPEC } \\
\end{array}$ & $\begin{array}{l}\text { February } \\
\text { 2016- } \\
\text { February } 2017\end{array}$ & $419(61.5)$ & $\begin{array}{l}\text { Ceftriaxone } \\
\text { J01DD04 (18.4) }\end{array}$ & $\begin{array}{l}\text { Co-amoxiclav- } \\
\text { J01CR02 (11.5) }\end{array}$ & $\begin{array}{l}\text { Cefotaxime } \\
\text { J0IDD01 (9.6) }\end{array}$ & 18.2 & 81.8 & $602(1.44)$ \\
\hline India [35] & LM & $\begin{array}{l}\text { Singh et al., } \\
2014\end{array}$ & 8 & One day & ARPEC & $\begin{array}{l}\text { November } \\
2012\end{array}$ & $192(98.4)$ & $\begin{array}{l}\text { Amikacin- } \\
\text { J01GB06- J01 } \\
(13.5)\end{array}$ & $\begin{array}{l}\text { Piperacillin plus } \\
\text { tazobactam- } \\
\text { J01CR05 } \\
(10.4)\end{array}$ & $\begin{array}{l}\text { Fluconazole- } \\
J 02 A C O 1(8.4)\end{array}$ & 71.0 & 29.0 & $431(2.2)$ \\
\hline $\begin{array}{l}\text { Turkey [38] } \\
\end{array}$ & UM & $\begin{array}{l}\text { Ceyhan et al., } \\
2010\end{array}$ & 12 & One day & Own & October 2007 & $711(54.6)$ & $\begin{array}{l}\text { Third-generation } \\
\text { cephalosporins- } \\
J 01 D D(16.6) \\
\end{array}$ & $\begin{array}{l}\text { Aminoglycosides } \\
J 01 G(16.6)\end{array}$ & $\begin{array}{l}\text { Carbapenems } \\
J 0 I D H(11.4)\end{array}$ & 18.7 & 73.4 & $1317(1.85)$ \\
\hline \multicolumn{14}{|l|}{ Africa } \\
\hline Ghana [39] & LM & $\begin{array}{l}\text { Labi et al., } \\
2018\end{array}$ & 10 & Period & ECDC & $\begin{array}{l}\text { September- } \\
\text { December } \\
2016 \\
\end{array}$ & $506(70.6)$ & $\begin{array}{l}\text { Ceftriaxone } \\
\text { J01DD04 (14.9) }\end{array}$ & $\begin{array}{l}\text { Gentamicin- } \\
\text { J01GBO3 (13.7) }\end{array}$ & $\begin{array}{l}\text { Cefuroxime } \\
\text { J01DC02 (12.4) }\end{array}$ & 23.7 & 71.5 & $831(1.6)$ \\
\hline \multicolumn{14}{|l|}{ America } \\
\hline USA [41] & $\mathrm{H}$ & $\begin{array}{l}\text { Grohskopf et } \\
\text { al., } 2005\end{array}$ & 31 & Repeated & PPN/CDC & $\begin{array}{l}\text { August } 1999- \\
\text { February } 2000\end{array}$ & 1440 (54.4) & $\begin{array}{l}\text { Gentamicin- } \\
\text { JolGB03 (16.9) }\end{array}$ & $\begin{array}{l}\text { Ampicillin-J0ICA01 } \\
(14.9)\end{array}$ & $\begin{array}{l}\text { Vancomycin- } \\
\text { J0IXAOI (12.9) } \\
\end{array}$ & - & - & $2647(1.84)$ \\
\hline \multicolumn{14}{|l|}{ Oceania } \\
\hline Australia [42] & $\mathrm{H}$ & $\begin{array}{l}\text { Osowicki et } \\
\text { al., } 2014\end{array}$ & 8 & Period & ARPEC & $\begin{array}{l}\text { May-July } \\
2012\end{array}$ & $631(46.0)$ & $\begin{array}{l}\text { Narrow spectrum } \\
\text { penicillins- } \\
\text { JOICE (18.0) }\end{array}$ & $\begin{array}{l}\text { Beta lactum plus } \\
\text { beta lactum } \\
\text { inhibitors- } \\
J 0 I C R(15.0) \\
\end{array}$ & $\begin{array}{l}\text { Aminoglycoside- } \\
J 01 G B(14.0)\end{array}$ & 37.0 & 62.0 & $1174(1.86)$ \\
\hline \multicolumn{14}{|l|}{$\begin{array}{l}\text { Eastern } \\
\text { Europe }\end{array}$} \\
\hline Russia [59] & UM & $\begin{array}{l}\text { Hajdu et al., } \\
2007\end{array}$ & 1 & One day & ECDC & February 2006 & $183(38.8)$ & $\begin{array}{l}\text { Third-generation } \\
\text { cephalosporins- } \\
\text { JOIDD (14.2) } \\
\end{array}$ & $\begin{array}{l}\text { Second-generation } \\
\text { cephalosporins } \\
\text { JOIDC (14.2) } \\
\end{array}$ & $\begin{array}{l}\text { Macrolides } \\
\text { JOIFA (9.5) }\end{array}$ & 13.0 & 84.0 & $211(1.15)$ \\
\hline \multicolumn{14}{|l|}{$\begin{array}{l}\text { Northern } \\
\text { Europe }\end{array}$} \\
\hline UK [60] & $\mathrm{H}$ & $\begin{array}{l}\text { Gharbi et al., } \\
2016\end{array}$ & 61 & Period & ARPEC & 2011-2012 & $1247(40.9)$ & - & - & - & - & 24.1 & 1858 (1.49) \\
\hline UK [61] & $\mathrm{H}$ & $\begin{array}{l}\text { Ang et al, } \\
2008\end{array}$ & 1 & Two Days & Own & 2008 & $177(49.3)$ & - & - & - & 28.4 & 70.3 & - \\
\hline Latvia [62] & $\mathrm{H}$ & $\begin{array}{l}\text { Sviestina and } \\
\text { Mozgis, } 2014\end{array}$ & 10 & One day & ARPEC & $\begin{array}{l}\text { November } \\
2012\end{array}$ & $192(35.0)$ & $\begin{array}{l}\text { Third-generation } \\
\text { cephalosporins } \\
J 01 D D(30.7) \\
\end{array}$ & 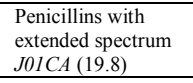 & $\begin{array}{l}\text { Betalactamase } \\
\text { sensitive penicillins } \\
J 0 I C E(13.5) \\
\end{array}$ & 19.2 & 80.8 & $235(1.22)$ \\
\hline \multicolumn{14}{|l|}{$\begin{array}{l}\text { Southern } \\
\text { Europe }\end{array}$} \\
\hline Italy [63] & $\mathrm{H}$ & $\begin{array}{l}\text { De Luca et } \\
\text { al., } 2016\end{array}$ & 7 & One day & ARPEC & $\begin{array}{l}\text { October - } \\
\text { December } \\
2012 \\
\end{array}$ & $349(38.9)$ & $\begin{array}{l}\text { Penicillin- } \\
\text { J01C }\end{array}$ & $\begin{array}{l}\text { Aminoglycoside- } \\
J 01 G B\end{array}$ & $\begin{array}{l}\text { Cephlosporin- } \\
\text { JOIDD }\end{array}$ & 37.0 & 63.0 & $543(1.56)$ \\
\hline $\begin{array}{l}\text { Germany \& } \\
\text { Croatia [44] }\end{array}$ & $\mathrm{H}$ & $\begin{array}{l}\text { Ufer M et al., } \\
2005 \\
\end{array}$ & 2 & Period & Own & 2005 & $104(17.4)$ & $\begin{array}{l}\text { Cephlosporin } \\
\text { J01D }\end{array}$ & $\begin{array}{l}\text { Penicillins } \\
J 0 I C\end{array}$ & $\begin{array}{l}\text { Aminoglycoside } \\
J 01 G\end{array}$ & 8.0 & 92.0 & - \\
\hline \multicolumn{14}{|l|}{ Multiregional } \\
\hline $21-\mathrm{EC}[43]$ & $3 \mathrm{UM} ; 18 \mathrm{H}$ & $\begin{array}{l}\text { Amadeo et } \\
\text { al., } 2010\end{array}$ & 32 & Period & ECDC & $\begin{array}{l}\text { May- June } \\
2008\end{array}$ & $583(32.4)$ & $\begin{array}{l}\text { Gentamicin- } \\
J 01 G B 03(13) \\
\end{array}$ & $\begin{array}{l}\text { Ceftriaxone } \\
\text { J01DD04 (10.1) } \\
\end{array}$ & $\begin{array}{l}\text { Ampicillin- } \\
\text { J01CA01 (9.3) }\end{array}$ & 26 & 71 & 839 (1.45) \\
\hline $41-\mathrm{C}[19]$ & $\begin{array}{l}\text { 5L;3 LM; } \\
6 \text { UM;27 H }\end{array}$ & $\begin{array}{l}\text { Versporten et } \\
\text { al., } 2016\end{array}$ & 226 & Period & ARPEC & $\begin{array}{l}\text { October- } \\
\text { November } \\
2012 \\
\end{array}$ & $6499(36.7)$ & $\begin{array}{l}\text { Penicillin } \\
\text { JolC }\end{array}$ & $\begin{array}{l}\text { Cephlosporin } \\
\text { JolD }\end{array}$ & $\begin{array}{l}\text { Aminoglycoside } \\
\text { J01G }\end{array}$ & 32.8 & 67.2 & $10196(1.57)$ \\
\hline $24-\mathrm{C}[64]$ & $\begin{array}{l}\text { 2L;2 LM; } \\
\text { 3 UM;17 H }\end{array}$ & $\begin{array}{l}\text { Versporten et } \\
\text { al., 2013 }\end{array}$ & 73 & One day & ARPEC & $\begin{array}{l}\text { September } \\
2011\end{array}$ & $2142(35.3)$ & - & - & - & - & - & - \\
\hline
\end{tabular}


ACH: Acute care Hospitals, ARPEC:Antibiotic Resistance and Prescribing in European Children, ECDC: European Centre of Disease Control and Prevention, GARPEC: Global Antimicrobial Resistance, Prescribing, and Efficacy in Neonates and Children, PPN: Pediatric Prevention Network, L: Low income, LM: Low Middle Income, UM: upper Middle Income, H: High Income

Table 2: Literature Review of Published Point-Prevalence Surveys (PPS) in Adults

\begin{tabular}{|c|c|c|c|c|c|c|c|c|c|c|c|c|c|}
\hline & $\begin{array}{l}\text { World Bank } \\
\text { Classification } \\
\text { by income }\end{array}$ & $\begin{array}{l}\text { Author Name } \\
\text { \& Date }\end{array}$ & $\begin{array}{l}\text { No. } \\
\text { of } \\
\text { ACH }\end{array}$ & $\begin{array}{l}\text { PPS } \\
\text { Method }\end{array}$ & $\begin{array}{l}\text { PPS } \\
\text { Protocol }\end{array}$ & $\begin{array}{c}\text { Study } \\
\text { Duration }\end{array}$ & $\begin{array}{c}\text { Antimicrobial } \\
\text { use rate }\end{array}$ & $\begin{array}{l}\text { Drug.1-ATC Code } \\
\text { (\%) }\end{array}$ & $\begin{array}{l}\text { Drug.2-ATC Code } \\
\text { (\%) }\end{array}$ & $\begin{array}{l}\text { Drug.3-ATC Code } \\
(\%)\end{array}$ & $\begin{array}{l}\text { Prophylaxis } \\
(\%)\end{array}$ & $\begin{array}{l}\text { Treatment } \\
(\%)\end{array}$ & $\begin{array}{l}\text { Antimicrobials } \\
\text { (Drugs/Patient) }\end{array}$ \\
\hline \multicolumn{14}{|l|}{ Eastern Asia } \\
\hline China [46] & UM & $\begin{array}{l}\text { Ren et al., } \\
2016\end{array}$ & 1313 & Period & Own & $\begin{array}{l}\text { March- } \\
\text { October } \\
2012\end{array}$ & $592111(75.3)$ & - & - & - & 39.7 & 60.3 & - \\
\hline China [22] & UM & $\begin{array}{l}\text { Xie et al., } \\
2015\end{array}$ & 13 & One Day & Own & $\begin{array}{l}\text { November } \\
2008\end{array}$ & $\begin{array}{l}6904 \\
(55.6)\end{array}$ & $\begin{array}{l}\text { Third-generation } \\
\text { cephalosporins- } \\
J 01 D D(26.3)\end{array}$ & $\begin{array}{l}\text { Fluoroquinolones- } \\
\text { JOIMA (15.2) }\end{array}$ & $\begin{array}{l}\text { Metronidazole- } \\
\text { J0IXD01(9.3) }\end{array}$ & 26.4 & 73.6 & $8682(1.26)$ \\
\hline Japan [65] & $\mathrm{H}$ & $\begin{array}{l}\text { Morioka et al., } \\
2018\end{array}$ & 4 & One Day & ECDC & $\begin{array}{ll}\text { July } 2016 \\
\end{array}$ & $933(29.2)$ & Cephalosporins-J0ID & $\begin{array}{l}\text { Co-trimoxazole- } \\
\text { JOIEE }\end{array}$ & Antimycotics- $J 02$ & - & - & $1318(1.4)$ \\
\hline $\begin{array}{l}\text { Japan [66] } \\
\end{array}$ & $\mathrm{H}$ & $\begin{array}{l}\text { Morioka et al., } \\
2016\end{array}$ & 1 & One Day & Own & $\begin{array}{ll}\text { July } 2014 \\
\end{array}$ & $308(36.6)$ & $\begin{array}{l}\text { Cephalosporins- } \\
J 01 D D \\
(33.0 \%) \\
\end{array}$ & $\begin{array}{l}\text { Antimycotics-J02 } \\
(14.9 \%)\end{array}$ & $\begin{array}{l}\text { Co-trimoxazole- } \\
\text { JOIEE }(14.9 \%)\end{array}$ & 60.7 & 37.7 & $494(1.6)$ \\
\hline \multicolumn{14}{|l|}{$\begin{array}{l}\text { Southern } \\
\text { Asia }\end{array}$} \\
\hline Pakistan [45] & LM & $\begin{array}{l}\text { Saleem et al., } \\
2019\end{array}$ & 13 & Period & Global & $\begin{array}{l}\text { October } \\
2017- \\
\text { February } \\
2018 \\
\end{array}$ & $1516(77.6)$ & $\begin{array}{l}\text { Ceftriaxone- } \\
\text { J0IDD04 (35.0) }\end{array}$ & $\begin{array}{l}\text { Metronidazole- } \\
\text { J0IXD0I(16.0) }\end{array}$ & $\begin{array}{l}\text { Ciprofloxacin } \\
\text { JOIMA02 (6.0) }\end{array}$ & 57.4 & 40.2 & $2483(1.64)$ \\
\hline Pakistan [67] & LM & $\begin{array}{l}\text { Saleem et al., } \\
2019\end{array}$ & 1 & Repeated & ECDC & $\begin{array}{l}\text { March 2018- } \\
2019\end{array}$ & $156(49.8)$ & $\begin{array}{l}\text { Piperacillin plus } \\
\text { tazobactam-J0ICR05 } \\
(31.8)\end{array}$ & $\begin{array}{l}\text { Meropenem- } \\
\text { JOIDHO2 (7.9) }\end{array}$ & $\begin{array}{l}\text { Ceftriaxone-J0IDD04 } \\
(6.2)\end{array}$ & 15.7 & 70.2 & $242(1.55)$ \\
\hline Sri Lanka[68] & LM & $\begin{array}{l}\text { Sheng et al., } \\
2019\end{array}$ & 5 & Period & - & $\begin{array}{l}\text { June-August } \\
2017\end{array}$ & $935(54.6)$ & $\begin{array}{l}\text { Co-amoxiclav- } \\
\text { J01CR02 (33.8) }\end{array}$ & $\begin{array}{l}\text { Third-generation } \\
\text { cephalosporins- } \\
\text { JoIDD (23.6) }\end{array}$ & $\begin{array}{l}\text { Metronidazole- } \\
\text { J0IXD0I(16.6) }\end{array}$ & - & - & - \\
\hline $\begin{array}{l}\text { India[69] } \\
\end{array}$ & LM & $\begin{array}{l}\text { Singh et al., } \\
2019\end{array}$ & 16 & Period & Global & $\begin{array}{l}\text { Oct-Dec } \\
2017\end{array}$ & 1005 (57.4) & $\begin{array}{l}\text { Ceftriaxone- } \\
\text { J01DD04 (34.0) }\end{array}$ & $\begin{array}{l}\text { Piperacillin plus } \\
\text { tazobactam-J01CR05 } \\
(8.0)\end{array}$ & $\begin{array}{l}\text { Meropenem- } \\
\text { JOIDH02 (8.0) }\end{array}$ & 45.9 & 46.7 & $1578(1.57)$ \\
\hline India [70] & LM & $\begin{array}{l}\text { Nair et al,, } \\
2015\end{array}$ & 1 & Repeated & Own & $\begin{array}{l}\text { March- } \\
\text { August } 2014 \\
\end{array}$ & $787(41.7)$ & $\begin{array}{l}\text { Cefotaxime } \\
\text { J0IDD01 (10.2) } \\
\end{array}$ & $\begin{array}{l}\text { Ceftriaxone- } \\
\text { J0IDD04 (8.9) } \\
\end{array}$ & $\begin{array}{l}\text { Amikacin- J01GB06 } \\
(7.9)\end{array}$ & 56.2 & 44.8 & $1940(2.47)$ \\
\hline \multicolumn{14}{|l|}{$\begin{array}{l}\text { South } \\
\text { Eastern } \\
\text { Asia } \\
\end{array}$} \\
\hline $\begin{array}{l}\text { Singapore [53] } \\
\end{array}$ & $\mathrm{H}$ & $\begin{array}{l}\text { Cai et al., } \\
2017\end{array}$ & 13 & Period & ECDC & $\begin{array}{l}\text { July 2015- } \\
\text { February } \\
2016 \\
\end{array}$ & $2762(51.0)$ & $\begin{array}{l}\text { Co-amoxiclav- } \\
\text { J01CR02 (24.6) }\end{array}$ & $\begin{array}{l}\text { Piperacillin plus } \\
\text { tazobactam- } \\
\text { J0ICR05 (9.2) } \\
\end{array}$ & $\begin{array}{l}\text { Ceftriaxone- } \\
\text { J01DD04 (7.7) }\end{array}$ & 12.8 & 83.0 & $3611(1.31)$ \\
\hline \multicolumn{14}{|l|}{ Western Asia } \\
\hline Qatar [71] & $\mathrm{H}$ & $\begin{array}{l}\text { Hammuda et } \\
\text { al., } 2013\end{array}$ & 1 & Repeated & ECDC & $\begin{array}{l}\text { April- } \\
\text { MayS } 2012\end{array}$ & $25(43.0)$ & $\begin{array}{l}\text { Penicillins plus Beta- } \\
\text { lactamase inhibitors- } \\
\text { JoICR }(39.4)\end{array}$ & $\begin{array}{l}\text { Carbapenems- } \\
\text { JOIDH (15.2) }\end{array}$ & $\begin{array}{l}\text { Fluoroquinolones- } \\
\text { JOIMA }(9.1)\end{array}$ & 6.1 & 93.9 & $33(1.32)$ \\
\hline $\begin{array}{l}\text { Saudi Arabia } \\
\text { [72] }\end{array}$ & $\mathrm{H}$ & $\begin{array}{l}\text { Matar et al., } \\
2019\end{array}$ & 26 & Period & $\begin{array}{l}\text { Global } \\
\text { PPS } \\
\end{array}$ & May 2016 & $2182(46.9)$ & $\begin{array}{l}\text { Ceftriaxone- } \\
\text { J01DD04 (11.7) } \\
\end{array}$ & $\begin{array}{l}\text { Metronidazole- } \\
\text { JOIXDOI (9.9) }\end{array}$ & $\begin{array}{l}\text { Cefuroxime } J 01 D C 02 \\
(6.9)\end{array}$ & 34.6 & 47.7 & $3240(1.48)$ \\
\hline Turkey [73] & UM & $\begin{array}{l}\text { Usluer et al., } \\
2005\end{array}$ & 18 & One Day & Own & March 2002 & $2900(30.6)$ & $\begin{array}{l}\text { Third-generation } \\
\text { cephalosporins- } \\
J O I D D(23.7) \\
\end{array}$ & $\begin{array}{l}\text { Aminoglycosides- } \\
\text { J01G (17.2) }\end{array}$ & $\begin{array}{l}\text { Flurouinolones- } \\
\text { JOIMA (14.4) }\end{array}$ & 44.2 & 48.8 & - \\
\hline \multicolumn{14}{|l|}{ Africa } \\
\hline Botswana[70] & UM & $\begin{array}{l}\text { Anand } \\
\text { Paramadhas et } \\
\text { al., } 2019\end{array}$ & 10 & Period & MURIA & $\begin{array}{l}\text { May-June } \\
2017\end{array}$ & $711(70.6)$ & $\begin{array}{l}\text { Cefotaxime } \\
\text { J01DD01 (20.3) }\end{array}$ & $\begin{array}{l}\text { Metronidazole- } \\
\text { J0IXD0I(12.8) }\end{array}$ & $\begin{array}{l}\text { Ampicillin-J0ICA0I } \\
(9.7)\end{array}$ & - & - & $982(1.38)$ \\
\hline $\begin{array}{l}\text { South } \\
\text { Africa[74] }\end{array}$ & UM & $\begin{array}{l}\text { Dlamini et al., } \\
2019\end{array}$ & 1 & Period & MURIA & $\begin{array}{l}\text { February- } \\
\text { March } 2017\end{array}$ & $193(37.7)$ & $\begin{array}{l}\text { Broad Spectrum } \\
\text { Penicillin- J01C } \\
\text { (34.1) }\end{array}$ & $\begin{array}{l}\text { Cephlosporin- } J 01 D \\
(17.9)\end{array}$ & $\begin{array}{l}\text { Antituberculosis- } \\
\text { J04A (12.0) }\end{array}$ & 5.2 & 89.2 & $306(1.59)$ \\
\hline Kenya[36] & LM & $\begin{array}{l}\text { Momanyi et } \\
\text { al. } 2019\end{array}$ & 1 & Period & MURIA & April 2017 & $97(54.7)$ & $\begin{array}{l}\text { Ceftriaxone- } \\
\text { J0IDD04 (39.7) } \\
\end{array}$ & $\begin{array}{l}\text { Benzyl Penicillin- } \\
\text { J0ICE08 (29.0) }\end{array}$ & $\begin{array}{l}\text { Metronidazole- } \\
\text { J01XD01(25.1) }\end{array}$ & 41.4 & 57.0 & $357(3.6)$ \\
\hline Kenya[54] & LM & $\begin{array}{l}\text { Okoth et al., } \\
2018\end{array}$ & 1 & Period & $\begin{array}{l}\text { Global } \\
\text { PPS }\end{array}$ & $\begin{array}{l}\text { June } \\
2017\end{array}$ & $182(67.7)$ & $\begin{array}{l}\text { Third-generation } \\
\text { cephalosporins- } \\
\text { JOIDD }\end{array}$ & $\begin{array}{l}\text { Imidazole } \\
\text { derivatives- P01, J02 }\end{array}$ & $\begin{array}{l}\text { Broad-spectrum } \\
\text { penicillins- } J 01 C A\end{array}$ & 51.0 & 41.0 & $333(1.80)$ \\
\hline
\end{tabular}




\begin{tabular}{|c|c|c|c|c|c|c|c|c|c|c|c|c|c|}
\hline $\begin{array}{l}\text { Nigeria [49] } \\
\end{array}$ & LM & $\begin{array}{l}\begin{array}{l}\text { Oduyebo et } \\
\text { al., } 2017\end{array} \\
\end{array}$ & 4 & Period & Own & \begin{tabular}{|l|} 
April- June \\
2015 \\
\end{tabular} & $577(69.7)$ & $\begin{array}{l}\text { Ceftriaxone- } \\
\text { J0IDD04 (18.9) }\end{array}$ & $\begin{array}{l}\text { Metronidazole- } \\
\text { JolXD01 (18.0) }\end{array}$ & $\begin{array}{l}\text { Ciprofloxacin } \\
\text { J0IMA02 }(9.9) \\
\end{array}$ & 38.8 & 51.2 & $1022(1.77)$ \\
\hline Congo [51] & $\mathrm{L}$ & $\begin{array}{l}\text { Wambale et } \\
\text { al., 2016 }\end{array}$ & 11 & Period & Own & $\begin{array}{l}\text { October } \\
2014 \\
\end{array}$ & $476(68)$ & $\begin{array}{l}\text { Ampicillin-J0ICA0I } \\
\text { (35.0) }\end{array}$ & $\begin{array}{l}\text { Gentamicin- } \\
\text { JolGB03 (13.6) }\end{array}$ & $\begin{array}{l}\text { Amoxicillin-J01CA04 } \\
(13.5)\end{array}$ & 4.0 & 96.0 & $667(1.40)$ \\
\hline \multicolumn{14}{|l|}{ Oceania } \\
\hline Australia [75] & $\mathrm{H}$ & $\begin{array}{l}\text { Cotta et al., } \\
2014\end{array}$ & 3 & Period & Own & \begin{tabular}{|l|} 
February \\
$2012-$ \\
February \\
2013 \\
\end{tabular} & $1125(32.4)$ & - & - & - & - & - & $1444(1.28)$ \\
\hline Australia [76] & $\mathrm{H}$ & $\begin{array}{l}\text { Ingram et al., } \\
2011\end{array}$ & 1 & Period & Own & \begin{tabular}{|l} 
September- \\
October \\
2010 \\
\end{tabular} & $199(43.0)$ & $\begin{array}{l}\text { Penicillins plus Beta- } \\
\text { lactamase inhibitors- } \\
J 0 I C R(31)\end{array}$ & $\begin{array}{l}\text { Fluoroquinolones- } \\
\text { JOIMA (12) }\end{array}$ & Penicillin-J01C (11) & 12.0 & 88.0 & $262(1.32)$ \\
\hline Australia [77] & $\mathrm{H}$ & $\begin{array}{l}\text { Ho and } \\
\text { Melvani, } 2007 \\
\end{array}$ & 1 & Repeated & Own & \begin{tabular}{|l|} 
April 2005- \\
April 2006
\end{tabular} & $508(34)$ & $\begin{array}{l}\text { Penicillin-J0IC } \\
(26.0)\end{array}$ & $\begin{array}{l}\text { Cephlosporins- } J 0 I D \\
(20.0)\end{array}$ & $\begin{array}{l}\text { Metronidazole- } \\
\text { J01XD01 (7.7) }\end{array}$ & 12 & 88 & $832(1.64)$ \\
\hline \multicolumn{14}{|l|}{ America } \\
\hline Canada [78] & $\mathrm{H}$ & $\begin{array}{l}\text { Lee et al., } \\
2015\end{array}$ & 1 & One Day & Own & July 2012 & $177(17.3)$ & $\begin{array}{l}\text { Fluoroquinolones- } \\
\text { JOIMA }\end{array}$ & $\begin{array}{l}\text { Third-generation } \\
\text { cephalosporins- } \\
\text { JOIDD }\end{array}$ & $\begin{array}{l}1^{\text {st }} \text { generation } \\
\text { cephalosporins- } \\
J 01 D B\end{array}$ & 10.7 & 87.0 & $249(1.41)$ \\
\hline $\begin{array}{l}\text { Canada [79] } \\
\end{array}$ & $\mathrm{H}$ & $\begin{array}{l}\text { Black et al., } \\
2018\end{array}$ & 13 & Period & ECDC & \begin{tabular}{|l|} 
June- \\
November \\
2015 \\
\end{tabular} & $458(30.6)$ & $\begin{array}{l}\text { Metronidazole- } \\
\text { JolXD01 (11.1) }\end{array}$ & $\begin{array}{l}\text { Cefazolin } \\
\text { J0IDB04 (10.9) }\end{array}$ & $\begin{array}{l}\text { Ceffriaxone-J0IDD04 } \\
(8.9)\end{array}$ & - & - & $660(1.4)$ \\
\hline USA [55] & $\mathrm{H}$ & $\begin{array}{l}\text { Magill et al., } \\
2014\end{array}$ & 183 & One Day & $\mathrm{CDC}$ & \begin{tabular}{|l|} 
May- \\
September \\
2011 \\
\end{tabular} & $5635(50.0)$ & $\begin{array}{l}\text { Vancomycin- } \\
\text { JOIXAOI (14.4) }\end{array}$ & $\begin{array}{l}\text { Ceftriaxone- } \\
\text { J0IDD04 (10.8) }\end{array}$ & $\begin{array}{l}\text { Piperacillin plus } \\
\text { tazobactam-J0ICR05 } \\
(10.3) \\
\end{array}$ & 18.1 & 77.5 & $9865(1.75)$ \\
\hline \multicolumn{14}{|l|}{$\begin{array}{l}\text { Northern } \\
\text { Europe }\end{array}$} \\
\hline Norway [57] & $\mathrm{H}$ & $\begin{array}{l}\text { Berild et al., } \\
2002\end{array}$ & 1 & Repeated & Own & \begin{tabular}{|l|}
$1996-1999$ \\
\end{tabular} & 1096 (16.6) & $\begin{array}{l}\text { Penicillin V and G- } \\
\text { JOICR (19.1) }\end{array}$ & $\begin{array}{l}\text { Ampicillin-J0ICA0I } \\
(16.9)\end{array}$ & $\begin{array}{l}\text { Dicloxacillin- } \\
\text { JOICFOI (10.9) } \\
\end{array}$ & 5.8 & 94.2 & $1370(1.25)$ \\
\hline Scotland [80] & $\mathrm{H}$ & $\begin{array}{l}\text { Seaton et al., } \\
2007\end{array}$ & 10 & One Day & GAAT & $\begin{array}{l}\text { December } \\
2003\end{array}$ & $1079(28.3)$ & $\begin{array}{l}\text { Third-generation } \\
\text { cephalosporins-- } \\
\text { JOIDD (28.3) }\end{array}$ & $\begin{array}{l}\text { Coamoxiclav- } \\
\text { J0ICR02 (20.2) }\end{array}$ & $\begin{array}{l}\text { Metronidazole- } \\
\text { JOIXDOI } \\
(19.2)\end{array}$ & - & - & - \\
\hline Ireland [81] & $\mathrm{H}$ & $\begin{array}{l}\text { Al-Taani et } \\
\text { al., } 2018\end{array}$ & 3 & Repeated & $\begin{array}{l}\text { Global } \\
\text { PPS }\end{array}$ & $\begin{array}{l}2009,2011, \\
2015\end{array}$ & $1239(34.4)$ & $\begin{array}{l}\text { Penicillins plus } \beta \text { - } \\
\text { lactamase inhibitors- } \\
\text { JoICR }\end{array}$ & $\begin{array}{l}\text { Penicillins with } \\
\text { extended spectrum- } \\
\text { J0ICA }\end{array}$ & Macrolides-JOIFA & 13.0 & 87.0 & $1752(1.41)$ \\
\hline Ireland [82] & $\mathrm{H}$ & $\begin{array}{l}\text { Aldeyab et al., } \\
2012\end{array}$ & 4 & Period & ECDC & $\begin{array}{l}\text { May-June } \\
2009\end{array}$ & $512(32.0)$ & $\begin{array}{l}\text { Co-amoxiclav- } \\
\text { JoICR02 (21.6) }\end{array}$ & $\begin{array}{l}\text { Piperacillin plus } \\
\text { tazobactam-J0ICR05 } \\
\text { (11.9) }\end{array}$ & $\begin{array}{l}\text { Metronidazole- } \\
\text { JOIXDDOI (9.1) }\end{array}$ & 15.9 & 84.1 & $713(1.39)$ \\
\hline \multicolumn{14}{|l|}{$\begin{array}{l}\text { Western } \\
\text { Europe }\end{array}$} \\
\hline $\begin{array}{l}\text { France [83] } \\
\end{array}$ & $\mathrm{H}$ & $\begin{array}{l}\text { Robert et al., } \\
2012\end{array}$ & 38 & One Day & $\begin{array}{l}\text { Own/ } \\
\text { ECDC }\end{array}$ & \begin{tabular}{|l} 
November \\
2009
\end{tabular} & $1619(40.8)$ & $\begin{array}{l}\text { Fluoroquinolones- } \\
J 01 M A \text { (23.6) }\end{array}$ & $\begin{array}{l}\text { Penicillins plus Beta- } \\
\text { lactamase inhibitors- } \\
J 01 C R(22.4)\end{array}$ & $\begin{array}{l}\text { Third and } \\
\text { Fourth-generation } \\
\text { cephalosporins- } \\
J 010 D D, D E(22.1)\end{array}$ & 21.2 & 78.8 & $\mathrm{~N} / \mathrm{A}$ \\
\hline Germany [84] & $\mathrm{H}$ & $\begin{array}{l}\text { Hansen et al., } \\
2013\end{array}$ & 132 & Period & ECDC & \begin{tabular}{|l|} 
September- \\
October \\
2011 \\
\end{tabular} & $10,593(25.5)$ & $\begin{array}{l}\text { Cefuroxime } \\
\text { J0IDC02 (14.3\%) }\end{array}$ & $\begin{array}{l}\text { Ciprofloxacin } \\
\text { J0IMA02 (9.8\%) }\end{array}$ & $\begin{array}{l}\text { Ceffriaxone-J01DD04 } \\
(7.5 \%)\end{array}$ & 30.0 & 70.0 & - \\
\hline Austria [85] & $\mathrm{H}$ & $\begin{array}{l}\text { Lusignani et } \\
\text { al., } 2016\end{array}$ & 9 & Period & $\begin{array}{l}\text { Own/ } \\
\text { ECDC }\end{array}$ & $\begin{array}{l}\text { May-June } \\
2012\end{array}$ & $1425(33.0)$ & $\begin{array}{l}\text { Amino-penicillin and } \\
\text { beta lactamase } \\
\text { inhibitors- J01CR } \\
(20.5 \%)\end{array}$ & $\begin{array}{l}\text { Fluroquinolones- } \\
\text { JOIMA (14.8\%) }\end{array}$ & $\begin{array}{l}\text { First and Second- } \\
\text { generation } \\
\text { cephalosporins- } \\
J O D D, \\
J 0 I D C(12.8 \%)\end{array}$ & N/A & $\mathrm{N} / \mathrm{A}$ & $1792(1.26)$ \\
\hline $\begin{array}{l}\text { Netherlands } \\
\text { [86] }\end{array}$ & $\mathrm{H}$ & $\begin{array}{l}\text { Akhloufi et } \\
\text { al., 2015 }\end{array}$ & 1 & Period & Own & May 2013 & $\begin{array}{l}337 \\
(33.8)\end{array}$ & $\begin{array}{l}\text { Fluoroquinolones- } \\
J 0 I M A(12.1)\end{array}$ & $\begin{array}{l}\text { Co-amoxiclav- } \\
\text { J01CR02 (11.1) }\end{array}$ & $\begin{array}{l}\text { Meropenem- } \\
\text { JOIDH02 (9.1) }\end{array}$ & 34.4 & 65.6 & $423(1.25)$ \\
\hline $\begin{array}{l}\text { Netherlands } \\
\text { [87] }\end{array}$ & $\mathrm{H}$ & $\begin{array}{l}\text { Willemsen et } \\
\text { al., } 2010\end{array}$ & 19 & Repeated & Own & 2008-2009 & $2327(29.6)$ & $\begin{array}{l}\text { Co-amoxiclav- } \\
\text { JoICR02 (26.3) }\end{array}$ & $\begin{array}{l}\text { Fluoroquinolones- } \\
\text { JOIMA (14.0) }\end{array}$ & $\begin{array}{l}\text { Third and fourth- } \\
\text { generation } \\
\text { cephalosporins- } \\
J O I D D, D E(7.3) \\
\end{array}$ & - & - & $2876(1.24)$ \\
\hline \multicolumn{14}{|l|}{$\begin{array}{l}\begin{array}{l}\text { Southern } \\
\text { Europe }\end{array} \\
\end{array}$} \\
\hline Italy [52] & $\mathrm{H}$ & $\begin{array}{l}\text { Antonioli et } \\
\text { al., } 2016\end{array}$ & 1 & Repeated & ECDC & $\begin{array}{l}\text { October } \\
2011- \\
\text { November } \\
2013\end{array}$ & $63(51.1)$ & $\begin{array}{l}\text { Fluoroquinolones- } \\
\text { JOIMA } \\
(23.0)\end{array}$ & $\begin{array}{l}\text { Penicillins plus Beta- } \\
\text { lactamase inhibitors- } \\
\text { JOICR }(19.2)\end{array}$ & $\begin{array}{l}\text { Third-generation } \\
\text { cephalosporins- } \\
J 0 I D D(16.6)\end{array}$ & - & - & $858(1.35)$ \\
\hline $\begin{array}{l}\text { Kosovo [88] } \\
\end{array}$ & UM & $\begin{array}{l}\text { Krasniqi et al., } \\
2017\end{array}$ & 7 & Period & ECDC & \begin{tabular}{|l|}
2013 \\
\end{tabular} & $767(46.0)$ & $\begin{array}{l}\text { Penicillin } \\
\text { JOIC }\end{array}$ & $\begin{array}{l}\text { Cephalosporins- } \\
\text { J0ID }\end{array}$ & $\begin{array}{l}\text { Aminoglycosides- } \\
J 01 G\end{array}$ & 91.0 & 9.0 & $1114(1.45)$ \\
\hline
\end{tabular}




\begin{tabular}{|c|c|c|c|c|c|c|c|c|c|c|c|c|c|}
\hline \multicolumn{14}{|l|}{$\begin{array}{l}\text { Eastern } \\
\text { Europe }\end{array}$} \\
\hline Slovak [89] & $\mathrm{H}$ & $\begin{array}{l}\text { Stefkovicova } \\
\text { et al., } 2016\end{array}$ & 40 & Period & ECDC & 2012 & 2575 (30.7) & $\begin{array}{l}\text { Fluoroquinolones- } \\
\text { JOIMA (20.9) }\end{array}$ & $\begin{array}{l}\text { Penicillins plus Beta- } \\
\text { lactamase inhibitors- } \\
\text { J0ICR } 15.7\end{array}$ & $\begin{array}{l}\text { Extended-spectrum } \\
\text { penicillins- } J 01 C A \\
(10.1)\end{array}$ & 28.0 & 61.3 & $3205(1.24)$ \\
\hline \multicolumn{14}{|l|}{ Multiregional } \\
\hline $53-\mathrm{C}[25]$ & $\begin{array}{l}2 \mathrm{~L} ; 6 \mathrm{LM} ; \\
17 \mathrm{UM} ; 28 \mathrm{H}\end{array}$ & $\begin{array}{l}\text { Versporten et } \\
\text { al., } 2018\end{array}$ & 335 & Period & $\begin{array}{l}\text { Global- } \\
\text { PPS }\end{array}$ & $\begin{array}{l}\text { January - } \\
\text { September } \\
2015\end{array}$ & $\begin{array}{l}29891(34 \cdot \\
4 \%)\end{array}$ & $\begin{array}{l}\text { Penicillins plus Beta- } \\
\text { lactamase inhibitors- } \\
\text { JOICR }\end{array}$ & $\begin{array}{l}\text { Third-generation } \\
\text { cephalosporins- } \\
\text { JoIDD }\end{array}$ & $\begin{array}{l}\text { Fluoroquinolones- } \\
\text { JOIMA }\end{array}$ & 25.2 & 74.8 & $41213(1.38)$ \\
\hline 23-EC [23] & $4 \mathrm{UM} ; 19 \mathrm{H}$ & $\begin{array}{l}\text { Zarb et al., } \\
2012\end{array}$ & 66 & Period & ECDC & $\begin{array}{l}\text { May- } \\
\text { October } \\
2010\end{array}$ & 6881 (34.6) & $\begin{array}{l}\text { Penicillins plus Beta- } \\
\text { lactamase inhibitors- } \\
\text { JOICR (16.3) }\end{array}$ & $\begin{array}{l}\text { Fluoroquinolones- } \\
\text { JOIMA (13.5) }\end{array}$ & $\begin{array}{l}\text { Second-generation } \\
\text { cephalosporins- } \\
\text { JOIDC (9.4) }\end{array}$ & 33.6 & 66.4 & $9588(1.39)$ \\
\hline 25 -EC [56] & $4 \mathrm{UM} ; 21 \mathrm{H}$ & $\begin{array}{l}\text { Zarb et al., } \\
2011\end{array}$ & 172 & Period & ECDC & 2009 & $21197(29.0)$ & $\begin{array}{l}\text { Penicillins/b- } \\
\text { lactamase } \\
\text { inhibitors (J01CR: } \\
22.1 \% \text { ) } \\
\end{array}$ & $\begin{array}{l}\text { Fluoroquinolones- } \\
\text { JOIMA (9.1) }\end{array}$ & $\mathrm{N} / \mathrm{A}$ & 19.2 & 80.8 & $29665(1.40)$ \\
\hline 20-EC [33] & $3 \mathrm{UM} ; 17 \mathrm{H}$ & $\begin{array}{l}\text { Ansari et al., } \\
2009\end{array}$ & 20 & Period & STRAMA & $\begin{array}{l}\text { April-May } \\
2006\end{array}$ & $3482(30.1)$ & $\begin{array}{l}\text { Penicillins plus Beta- } \\
\text { lactamase inhibitors- } \\
\text { JOICR (24.0) }\end{array}$ & $\begin{array}{l}\text { Macrolides- } J 01 F \\
(15.2)\end{array}$ & $\begin{array}{l}\text { Fluoroquinolones- } \\
\text { JOIMA (11.2) }\end{array}$ & 23.3 & 76.7 & $4748(1.36)$ \\
\hline 5-EC [90] & $1 \mathrm{UM} ; 4 \mathrm{H}$ & $\begin{array}{l}\text { Vlahović́ } \\
\text { Palčevski et } \\
\text { al, 2007 }\end{array}$ & 5 & One Day & Own & May 2003 & 1025 (24.8) & $\begin{array}{l}\text { Cefazolin } \\
\text { J0IDB04 }\end{array}$ & $\begin{array}{l}\text { Ciprofloxacin } \\
\text { JOIMA02 }\end{array}$ & $\begin{array}{l}\text { Cefuroxime } \\
\mathrm{J} 01 \mathrm{DCO2}\end{array}$ & 26 & 64 & $1218(1.19)$ \\
\hline 28-EC [31] & $5 \mathrm{UM} ; 23 \mathrm{H}$ & $\begin{array}{l}\text { Plachouras et } \\
\text { al., } 2018\end{array}$ & 1209 & Period & ECDC & 2016-2017 & $102,093(32.9)$ & $\begin{array}{l}\text { Amoxicillin and } \\
\text { beta-lactamase } \\
\text { inhibator (J01CR02) }\end{array}$ & $\begin{array}{l}\text { Piperacillin and beta- } \\
\text { lactamase inhibator } \\
\text { (J01CR05) }\end{array}$ & $\begin{array}{l}\text { Ceftriaxone } \\
\text { (J01CR04) }\end{array}$ & 24.9 & 70.9 & $139,609(1.4)$ \\
\hline
\end{tabular}

ACH: Acute care Hospitals, ARPEC:Antibiotic Resistance and Prescribing in European Children, ECDC: European Centre of Disease Control and Prevention, L: Low income, LM: Low Middle Income, UM: upper Middle Income, H: High Income 
Table 3: Antimicrobial use in hospital inpatients, by $\mathrm{UN}$ region

\begin{tabular}{|l|l|l|l|l|}
\hline & & & \multicolumn{2}{l|}{ Country Range } \\
\hline UN-region & $\begin{array}{l}\text { Prevalence of } \\
\text { antimicrobial } \\
\text { use (\%, country } \\
\text { range) }\end{array}$ & $\begin{array}{l}\text { Mean AMU } \\
\text { prevalence (\%) }\end{array}$ & Lower (\%) & Upper (\%) \\
\hline East Europe & $34.7(30.7-38.8)$ & 34.7 & 30.7 & 38.8 \\
\hline North Europe & $33.8(16.6-49.3)$ & 33.8 & 16.6 & 49.3 \\
\hline South Europe & $38.3(17.4-51.1)$ & 38.3 & 17.4 & 51.1 \\
\hline West Europe & $32.5(25.5-40.8)$ & 32.5 & 25.5 & 40.8 \\
\hline Africa & $62.7(37.7-70.6)$ & 62.7 & 37.7 & 70.6 \\
\hline Asia & $55.3(29.2-98.4)$ & 55.3 & 29.2 & 98.4 \\
\hline Oceania & $38.9(32.4-46.0)$ & 38.9 & 32.4 & 46.0 \\
\hline America & $38.1(17.3-54.4)$ & 38.1 & 17.3 & 54.4 \\
\hline
\end{tabular}

